\title{
Mitigating Source Water Risks with Improved Wildfire Containment
}

\author{
Benjamin M. Gannon ${ }^{1,2, *}$, Yu Wei ${ }^{1}$ (1) and Matthew P. Thompson ${ }^{3}$ \\ 1 Department of Forest and Rangeland Stewardship, Colorado State University, Fort Collins, CO 80523, USA; \\ yu.wei@colostate.edu \\ 2 Colorado Forest Restoration Institute, Colorado State University, Fort Collins, CO 80523, USA \\ 3 Rocky Mountain Research Station, USDA Forest Service, Fort Collins, CO 80526, USA; \\ matthew.p.thompson@usda.gov \\ * Correspondence: benjamin.gannon@colostate.edu
}

Received: 21 July 2020; Accepted: 20 August 2020; Published: 21 August 2020

check for updates

\begin{abstract}
In many fire-prone watersheds, wildfire threatens surface drinking water sources with eroded contaminants. We evaluated the potential to mitigate the risk of degraded water quality by limiting fire sizes and contaminant loads with a containment network of manager-developed Potential fire Operational Delineations (PODs) using wildfire risk transmission methods to partition the effects of stochastically simulated wildfires to within and out of POD burning. We assessed water impacts with two metrics-total sediment load and frequency of exceeding turbidity limits for treatment-using a linked fire-erosion-sediment transport model. We found that improved fire containment could reduce wildfire risk to the water source by 13.0 to $55.3 \%$ depending on impact measure and post-fire rainfall. Containment based on PODs had greater potential in our study system to reduce total sediment load than it did to avoid degraded water quality. After containment, most turbidity exceedances originated from less than $20 \%$ of the PODs, suggesting strategic investments to further compartmentalize these areas could improve the effectiveness of the containment network. Similarly, risk transmission varied across the POD boundaries, indicating that efforts to increase containment probability with fuels reduction would have a disproportionate effect if prioritized along high transmission boundaries.
\end{abstract}

Keywords: water supply; erosion; wildfire containment; Potential fire Operational Delineations; Monte Carlo simulation; transmission risk

\section{Introduction}

Improved wildfire containment is an attractive strategy to mitigate the risk of degrading water quality beyond limits for treatment because of the potential to limit fire sizes and impacts to tolerable levels without the need to completely exclude fire from the landscape. Recent efforts to make containment planning more proactive, focus on zoning the landscape into fire management units called Potential fire Operational Delineations (PODs) using existing high probability control features such as roads, rivers, and fuel transitions [1,2]. Beyond the inherent value of engaging managers in the process to identify and critique potential control features, the resulting POD areas become relevant spatial units for pre-fire analysis of endogenous and transmitted wildfire risk to inform response strategies that are appropriate for the predicted direction and magnitude of fire effects to water supplies and other natural resources and human assets [2]. While there has been substantial progress engaging managers in the bottom up approach to develop and employ PODs and their associated response strategies [2-8], less attention has been paid to evaluating the risk mitigation effectiveness of containing wildfire within these units and what functional improvements should be made to the size and spatial arrangement 
of the containers to maximize their protection benefit for water supplies and other values, such as wildlife, that depend on the scale of fire activity.

Wildfire is often harmful to water quality because reductions in surface cover and infiltration cause increases in surface runoff and erosion that can mobilize and transport contaminants into surface drinking water sources [9-12]. While the specific contaminants and concentrations of concern may vary by watershed and water system [12-14], water quality degradation generally becomes problematic when large quantities of sediment are mobilized by intense rainfall causing contaminant concentrations to exceed thresholds for effective water treatment (e.g., [15]). Post-fire sediment loads are influenced by fire size and burn severity, topography, soil properties, and rainfall intensity $[10,16,17]$. Previous efforts to account for fire effects on watersheds and water supplies account for some of these factors $[18,19]$, but the use of relative fire effects measures makes it difficult to evaluate whether a given fire will degrade water quality. This shortcoming has been addressed in recent years with increasing use of spatially explicit erosion and sediment transport models to make quantitative predictions of sediment yield from modeled wildfires (e.g., [20-24]). Sediment yield models have been widely used to examine the risk mitigation effectiveness of area-wide fuel treatments meant to reduce burn severity [23-26] but they have not yet been used to evaluate the performance of fire containment strategies to reduce area burned.

Some water systems have discrete features, such as terminal reservoirs, that could be targeted for protection within a single POD, but many municipal watersheds in the western USA are hundreds to thousands of square kilometers in size and therefore require some level of internal compartmentalization to protect water supplies. In theory, the size and spatial arrangement of PODs could be designed to mitigate the risk of water quality degradation by both containing fires with potential for large growth and subsequent contaminant loads near their ignition sources and ensuring that within-POD burning does not result in adverse consequence. Managers consider both values at risk and presence of control features when delineating PODs, which often results in smaller PODs near developed areas and larger PODs in the backcountry [2,4]. However, it is not clear that the size and configuration of manager-delineated PODs will reduce risk of wildfire-related water quality degradation. Several attempts have been made to automate the processes of identifying suitable control features and aggregating them into PODs $[27,28]$ using roads, streams, watershed boundaries, and spatial models of suppression difficulty and potential for control [29-31], but data-driven approaches have yet to inform the desired size and spatial configuration of PODs to mitigate a particular risk.

Recognizing the importance of fire size, location, and burn severity for watershed response, several previous studies have employed Monte Carlo wildfire simulation to characterize watershed exposure and water supply risk [19,32-34]. Their results suggest that most risk to water supplies is associated with a small subset of total fire activity. Moreover, the source locations of damaging wildfires tend to cluster in certain parts of the landscape, which implies containment benefits will depend strongly on location. Simulated fire ignition locations and fire extents can be intersected with relevant management units to partition fire impacts from burning within the unit of origin and transmission to the surrounding landscape $[2,35,36]$. Analyzing risk transmission across a network of PODs could help to identify locations with high source risk that would benefit from investment in activities to improve containment probability, such as roadside fuels reduction. Areas with fuels conducive to fast fire spread tend to transmit the most fire [36], which will result in high water supply risk when adjacent areas have high erosion potential and/or short transport paths to water supplies. Analysis of water supply risk from self-burning could also identify high risk PODs that would benefit from further compartmentalization.

The goal of this study is to provide a proof of concept model to evaluate the effectiveness of a containment network at mitigating risk of source water quality degradation. The general approach should also be relevant for assessing risk to other resources that depend on disturbance size. We utilized Monte Carlo wildfire simulation, erosion, and sediment transport modeling to quantify the potential water supply impacts from a set of simulated wildfires with and without containment. We analyzed 
risk and risk mitigation with two measures of water supply impact - total sediment load and frequency of exceeding turbidity limits for treatment-to highlight how considering the scale-dependent effects of wildfire changes the perceived mitigation value of fire containment. Risk transmission was analyzed to identify possible improvements to the containment network with measures of transmitted risk highlighting those PODs and POD boundaries that could benefit from activities to improve containment probability and measures of self-burning indicating areas in need of further compartmentalization.

\section{Materials and Methods}

\subsection{Evaluation Framework}

The evaluation framework was designed to contrast the water quality impacts of uncontained wildfires and wildfires contained within the POD of origin in terms of total sediment load and average post-storm suspended sediment (Figure 1). Total sediment load is similar to the commonly used net value change measures in risk assessment $[37,38]$ insomuch as more is interpreted as bad and any marginal reduction decreases risk. However, using change in total sediment load as a measure of risk has the potential to falsely assign mitigation benefit to containment when either the load from the uncontained wildfire is already below a meaningful threshold of water quality degradation or containment reduces erosion but the resulting load is still above the treatment threshold. Average post-storm suspended sediment concentration is used here to estimate whether fires will degrade water quality beyond limits for water treatment and whether degradation outcomes change with containment. This measure of risk better approximates the threshold-dependent nature of water quality degradation owing to the size of the receiving waterbody and the water system sensitivity to contaminants.

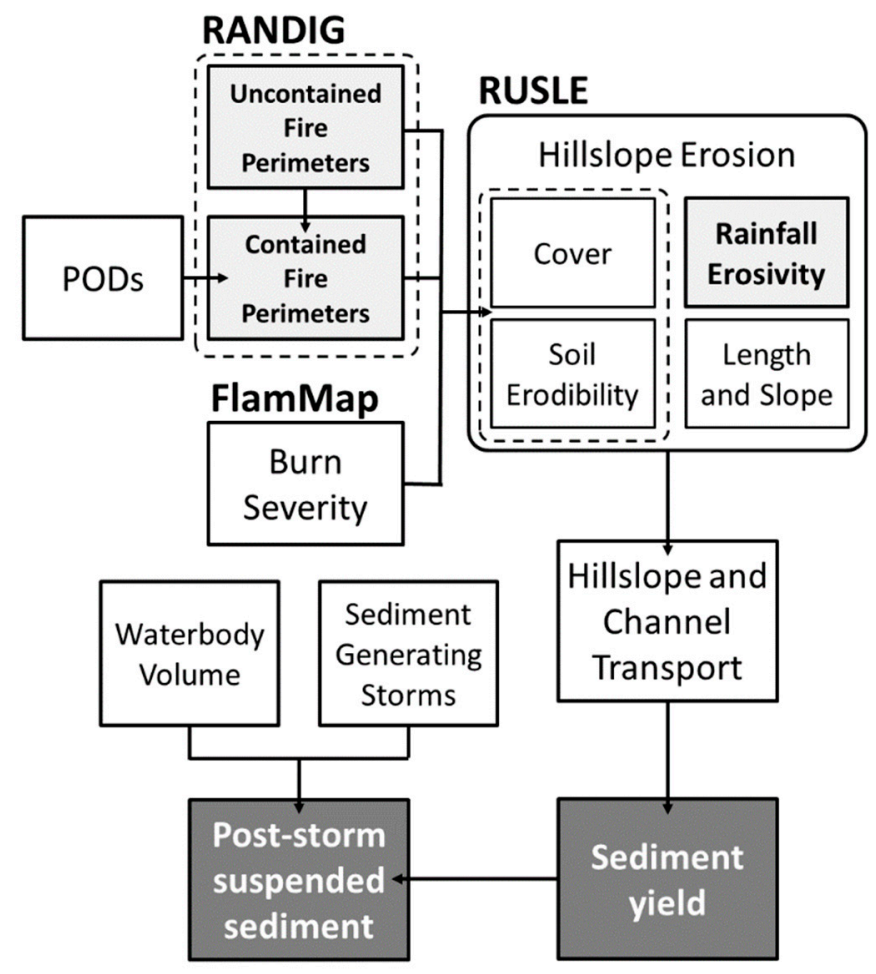

Figure 1. The evaluation framework focuses on total sediment yield and average post-storm suspended sediment as measures of water quality degradation risk. Variable inputs are in light grey. Stochastically simulated wildfire perimeters were combined with estimates of burn severity to model post-fire erosion and sediment transport to the water supply both with and without containment. Sediment yield was converted to average post-storm suspended sediment concentration using the receiving waterbody volume and the annual frequency of sediment generating storms. 
Our evaluation framework focuses on the key uncertainties in wildfire-water quality degradation risk related to the extent of the watershed burned and post-fire rainfall (Figure 1). As further described in following sections, many plausible wildfire perimeters were simulated with the Monte Carlo ignition and spread model RANDIG [35,39], which were then clipped to their POD of origin to approximate a strategy of improved containment. Post-fire erosion was then simulated for each perimeter using crown fire activity predicted with FlamMap 5.0 [40] as a proxy for burn severity to modify the cover and soil variables in the Revised Universal Soil Loss Equation (RUSLE) [41]. We accounted for uncertainty in post-fire rainfall by modeling erosion for three rainfall scenarios ranging from common to extreme. We estimated annual sediment loads to the water supply based on the predicted proportion of sediment transported off hillslopes and through channels using Sediment Delivery Ratio (SDR) models [42,43]. Post-storm suspended sediment concentrations were estimated by assuming average storm sediment loads are diluted in the mean daily flow volume of the river during the May to October thunderstorm season, which is associated with most post-fire erosion and water quality degradation in the study region [15,16]. All analyses were completed with $\mathrm{R}$ version 3.5.3 [44] except where noted otherwise.

\subsection{Study Area}

The study area encompasses $3021 \mathrm{~km}^{2}$ of the Front Range Mountains in Colorado, USA (Figure 2). The Front Range has a history of large and severe fires that have caused extreme erosion, reservoir sedimentation, and water quality degradation [15,45-48]. The names of the focal municipal water supply and other geographic features within the study area are withheld for security reasons. The extent of the study area was defined to include the contributing area to a municipal pipeline diversion $\left(1254 \mathrm{~km}^{2}\right)$ and a network of PODs developed by the local National Forest and their partnering state and local fire management agencies (an additional $1767 \mathrm{~km}^{2}$ ). PODs that intersected a $5 \mathrm{~km}$ buffer around the watershed were included to analyze fires that spread into the watershed from nearby areas. Elevation ranges from 1559 to $4135 \mathrm{~m}$ above sea level across the study area. The climate is continental with warm dry summers and cold winters. Most erosion in this region results from intense rainstorms during the summer and early fall $[16,49]$. The study area is primarily forest $(71.7 \%$, most of which is dominated by conifers) and the remainder is a mix of shrubland (9.0\%), sparsely vegetated alpine $(8.9 \%)$, and grassland (8.7\%) [50]. Land ownership is split between the USDA Forest Service (55.3\%), private (18.8\%), National Park Service (18.1\%), local government (6.4\%), and state (1.4\%).

\subsection{Potential Fire Operational Delineations}

PODs were developed by fire and resource management specialists from the local National Forest and external fire management partners from other federal, state, and local agencies. The PODs range in size from 502 to 23,672 ha with a mean of 4316 ha and a median of 3516 ha. The PODs tend to be smallest near human settlements due to both the increased presence of control features and greater need for fire containment around communities. PODs larger than 10,000 ha are clustered in the higher elevation, western portion of the of the study area where much of the land is publicly owned and the transportation network is sparse. PODs also tend to be large along the major river canyon that runs west to east across the study area (Figure 2) due to limited presence of high probability control features other than the river and highway in the canyon bottom.

The rugged topography, rocky soils, and dense forests of the study area are major constraints on firefighter and equipment accessibility and operability. Accordingly, managers preferentially chose roads as the control features to bound PODs; of the $1386 \mathrm{~km}$ of POD edge, $985 \mathrm{~km}$ are roads (71.0\%), $167 \mathrm{~km}$ are trails $(12.0 \%), 150 \mathrm{~km}$ are ridges $(10.8 \%), 46 \mathrm{~km}$ are streams (3.3\%), and the remaining $40 \mathrm{~km}$ are fuel transitions, lakes/reservoirs, or lacking defined control features (2.9\%). Many of the trails and ridges selected as control features are in barren or sparsely vegetated areas of the alpine, so roads make up an even larger proportion of POD edges in the fuel types where wildfire transmission is a concern. Numerous observational studies have documented that roads benefit fire control by serving as hard fire breaks that either stop fires passively or in combination with suppression firing or holding 
activities [30,51-53]. The frequent use of roads in this POD network suggests containment probability should be high along most boundaries under low to moderate fire weather and many boundaries have potential for containment under more extreme conditions with well-coordinated suppression tactics.

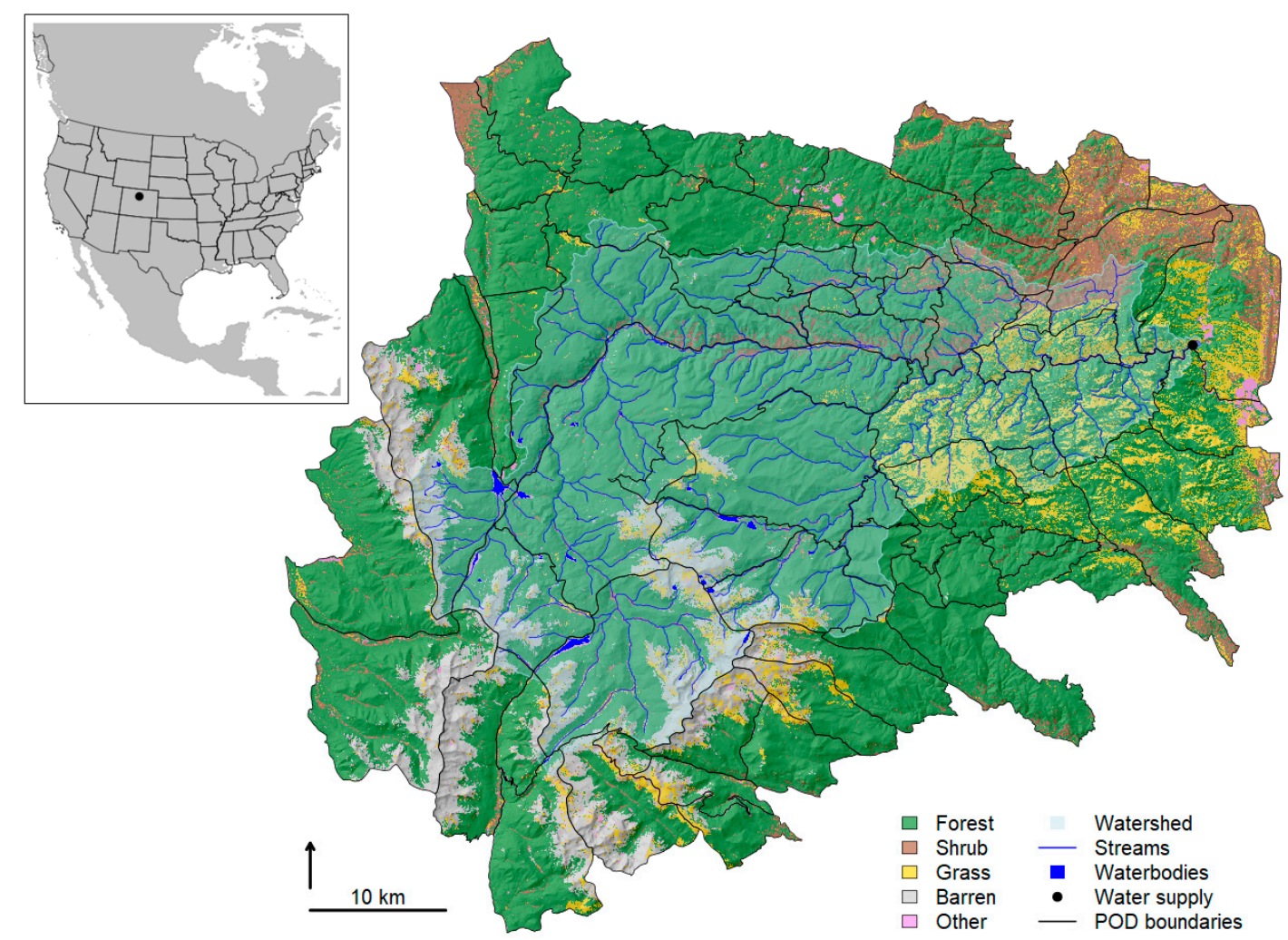

Figure 2. Map of the study area featuring the focal watershed and PODs that intersect a five $\mathrm{km}$ buffer around the watershed. Landcover is from LANDFIRE [50]. Barren is sparsely vegetated alpine. The inset maps the location of the study area in the USA.

\subsection{Fire Occurrence}

We used the Monte Carlo fire simulation program RANDIG, which is a command-line version of the FlamMap minimum travel time module [39], to model a plausible set of 5000 large fire growth events across the study area. The inputs to RANDIG include raster surfaces of fuels, topography, and ignition density, and a set of fire scenarios describing the fuel moisture, wind speed, wind direction, spot probability, and burn duration for the simulations and their probabilities of occurrence. The intent of our model parameterization is to approximate the distribution of potential area burned during the initial growth period of large fires owing to variation in wind direction and wind speed. We focused on the early growth period of fires to align with the desire to contain most fires before they leave the POD of origin. Modeling fire growth over longer periods would increase fire size and thus the avoided area burned and water quality impacts but would also introduce greater uncertainty about final fire extent as more potential containment features are encountered and weather conditions are likely to moderate.

Raster fuels and topography data representing landscape conditions circa 2014 were acquired from LANDFIRE [50] including canopy cover, canopy bulk density, canopy base height, canopy height, surface fire behavior fuel model [54], elevation, slope, and aspect. Fuels were adjusted in lodgepole pine (Pinus contorta var. latifolia) forests by lowering the canopy base height by $20 \%$ and changing the fire behavior fuel model to high load conifer litter (TL5 from [54]) to better match recent observations of extreme fire behavior in these forests [55]. The other spatial input is a raster surface of ignition density, which influences the relative probability of fire ignition across the modeling domain. Spatial point 
locations of historical fires from Short [56] were generalized into a raster surface of ignition density using a kernel density function with a search distance of $10 \mathrm{~km}$ in ArcGIS 10.3 [57].

Fuel moisture, wind speed, and wind direction for the fire scenarios (Table 1) were informed by data from a Remote Automated Weather Station [58] located in the northern half of the study area at $2500 \mathrm{~m}$ above sea level. Fuel moisture and wind speed percentiles were calculated with FireFamilyPlus 4.1 [59] and wind speed was converted from a 10-min to 1-min average based on Crosby and Chandler [60]. Most large fires in this region occur in early summer during drought years or in the fall when fuel moisture is extremely low. These conditions were approximated using the historical 3rd percentile fire season (1 April-31 October) fuel moistures, which are 2, 3, 6, 30, and 60 percent for the 1-h, 10-h, 100-h, herbaceous, and woody fuels, respectively. Fuel moisture was held constant across all wind scenarios because it exhibits little meaningful variation below the 10th percentile. Wind scenarios were designed to approximate the joint probability distribution of wind speeds and directions that are problematic for fire growth. The 50th, 90th, and 97th percentiles of 1-min average wind speeds are 19.3, 33.8, and $43.5 \mathrm{kph}$ (at $6 \mathrm{~m}$ ). We generalized these into three levels of wind speed (16.1, 32.2 , and $48.3 \mathrm{kph})$ and their associated spotting probabilities $(0.02,0.05$, and 0.10$)$ that we assigned relative probabilities of occurrence of $0.90,0.07$, and 0.03 . Previous large fires in this landscape are associated with strong westerly winds and our analysis of the historical record found that $74.1 \%$ of all winds greater than or equal to $16.1 \mathrm{kph}$ were from the northwest, west, or southwest, which have relative probabilities of occurrence equal to $0.29,0.48$, and 0.23 . We combined the three levels of wind speed and spotting probabilities with the three variations of wind direction into a total of nine fire scenarios (Table 1). Burn duration was set to four hours for all scenarios, which was determined by incrementally adjusting burn duration in $30 \mathrm{~min}$ time steps until the largest simulated fire was within $\pm 5 \%$ of 20,000 ha, which we judge as a reasonable upper bound for fire size during a single burn period in this landscape based on other fires in the region [46].

Table 1. Fire scenarios used to simulate fires in RANDIG. Burn duration was set to $240 \mathrm{~min}$ and fuel moisture was held constant at the 3rd percentile of the historical record.

\begin{tabular}{ccccc}
\hline Scenario & Wind Speed $\mathbf{( k p h}$ at $\mathbf{6 ~} \mathbf{~ m})$ & Direction $\mathbf{( d e g})$ & Spot Probability & Scenario Probability \\
\hline 1 & 16.1 & 225 & 0.02 & 0.259 \\
2 & 16.1 & 270 & 0.02 & 0.431 \\
3 & 16.1 & 315 & 0.02 & 0.210 \\
4 & 32.2 & 225 & 0.05 & 0.020 \\
5 & 32.2 & 270 & 0.05 & 0.034 \\
6 & 32.2 & 315 & 0.05 & 0.016 \\
7 & 48.3 & 225 & 0.1 & 0.009 \\
8 & 48.3 & 270 & 0.1 & 0.014 \\
9 & 48.3 & 315 & 0.1 & 0.007 \\
\hline
\end{tabular}

\subsection{Fire Behavior and Severity}

Crown fire activity [61] was modeled as a proxy for burn severity with FlamMap 5.0 [40] by mapping surface fire, passive crown fire, and active crown fire to low, moderate, and high severity, respectively. Crown fire activity is commonly used to estimate burn severity for watershed modeling $[24,33,62]$ because it captures the trend of increasing fire intensity along the gradient of surface to active crown fire behavior. Fuel moisture was set to the same 3rd percentile fuel moisture described in the fire occurrence section. The same topography and modified fuels rasters were also used as the landscape inputs to FlamMap. To simplify the analysis, we modeled burn severity for the middle wind speed scenario ( $32.2 \mathrm{kph}$ at $6 \mathrm{~m}$ ) and used the wind blowing uphill option to represent a consistent worst-case scenario for all aspects.

\subsection{Post-Fire Watershed Response}

Post-fire erosion and sediment transport to the water diversion was predicted with a system of coupled hillslope erosion, hillslope sediment transport, and channel sediment transport models 
(Figure 1) that has been calibrated to make reasonable predictions of post-fire sediment yields within the study region [24]. The NHDPlus raster and watershed network products [63] were used to represent the topological connections between upland sediment sources and the water diversion point via sub-catchment drainage paths to the flowline network and the series of intervening flowlines between each catchment and the diversion. First, gross hillslope erosion was modeled for each fire with a raster Geographic Information System implementation [64] of RUSLE [41]. Sediment transport to streams was predicted using an empirical model of post-fire hillslope sediment delivery ratio from the western USA [42] to estimate the proportion of sediment generated in each pixel that makes it to the flowline network. Third, the total sediment from each catchment was routed down the flowline network to the diversion point using a simple model of channel sediment delivery ratio [43] adapted for the channel types in the study area.

\subsubsection{Hillslope Erosion}

RUSLE predicts gross erosion $\left(\mathrm{Mg} \mathrm{ha}^{-1}\right.$ year $\left.^{-1}\right)$ as the product of factors for rainfall erosivity $(\mathrm{R})$, soil erodibility (K), length and slope (LS), cover (C), and support practices (P) [41]. Rainfall erosivity is calculated as the product of storm maximum rainfall intensity and kinetic energy per unit area [41]. First year post-fire erosion was modeled at three levels of May to October rainfall erosivity-403, $887,5168 \mathrm{MJ} \mathrm{mm} \mathrm{ha}^{-1} \mathrm{~h}^{-1}$-representing the 2, 10, and 100-year recurrence interval rainfall erosivity (hereafter "rainfall erosivity") for the regional climate $[65,66]$. The May through October period was selected because most post-fire erosion in this region occurs in response to high intensity summer rainfall [16]. LS was calculated from a $30 \mathrm{~m}$ resolution digital elevation model [63] following the methods of Winchell et al. [67] with a maximum limit on flow accumulation of 0.9-ha imposed to approximate the original hillslope length guidance in Renard et al. [41]. Baseline K came from the Soil Survey Geographic Database where available and the State Soil Geographic Database to fill missing data [68]. Post-fire erosion was simulated by modifying the $\mathrm{K}$ and $\mathrm{C}$ factors based on wildfire extent and burn severity $[24,69]$. No support practices were considered to model the unmitigated erosion hazard. Baseline erosion is not a major concern for water quality, so we focused our assessment on the post-fire increase in erosion. First-year post-fire increase in erosion (A) was calculated with Equation (1) for each level of rainfall erosivity.

$$
\mathrm{A}=\mathrm{R} \times \mathrm{LS} \times\left[\left(\mathrm{K}_{\mathrm{b}} \times \mathrm{C}_{\mathrm{b}}\right)-(\mathrm{K} \times \mathrm{C})\right],
$$

The subscript $\mathrm{b}$ indicates the burned condition for $\mathrm{K}$ and $\mathrm{C}$ factors. We limited hillslope erosion predictions to $100 \mathrm{Mg} \mathrm{ha}^{-1}$ year $^{-1}$ based on the maximum observed values reported in the study region [49].

\subsubsection{Hillslope Sediment Transport}

An empirical model of post-wildfire hillslope sediment delivery ratio (hSDR) from the western USA [42] was used to estimate the proportion of sediment generated in each pixel that makes it to the stream network. The NHDPlus flowlines were first extended to include all pixels with a contributing area greater than 10.8 ha [70] to better approximate the extent of the post-fire channel network. Post-fire hSDR was then estimated with the annual length ratio model from Wagenbrenner and Robichaud [42]. We applied this model to predict hSDR as a function of the flow path length from each pixel to the nearest stream channel as the "catchment length" and the flow path length across the pixel as the "plot length" (Equation (2)). Flow path length to the nearest channel was calculated from a $30 \mathrm{~m}$ digital elevation model [63] in ArcGIS 10.3 [57]. We doubled the predicted hSDR to account for under-sampling of suspended sediment in the model training data and to roughly calibrate our net sediment yield predictions to the small catchment yields from the Hayman Fire in Colorado [42]. This increased the maximum hSDR from 0.27 to 0.54 for areas near streams and it increased the minimum hSDR from 0.05 to 0.10 for locations furthest from streams. We later compare our modeled gross and net hillslope 
sediment yields to relevant field observations in the discussion to demonstrate that this assumption is reasonable. Channel pixels were assigned hSDR of 1 .

$$
\log (\mathrm{hSDR})=-0.56-0.0094 \times(\text { flow path length to channel/flow path length across pixel) }
$$

The first-year mass of sediment $(\mathrm{Mg})$ delivered from a catchment to the stream network (TS) was calculated as the sumproduct of the post-fire hillslope erosion (A), the pixel area, and hSDR for all burned pixels $(\mathrm{N})$ in the catchment (Equation (3)).

$$
\mathrm{TS}=\operatorname{SUM}\left(\mathrm{A}_{\mathrm{i}} \times 0.09 \mathrm{ha} / \text { pixel } \times \mathrm{hSDR}_{\mathrm{i}}\right) \mid \mathrm{i}=1 \text { to } \mathrm{i}=\mathrm{N},
$$

\subsubsection{Channel Sediment Transport}

Sediment was routed through the NHDPlus flowline network to the diversion by adapting the channel sediment delivery ratio (cSDR) model of Frickel et al. [43] to the channel types in the study watershed [24]. In montane streams of this region, sediment retention is generally highest in low order channels because of high roughness and limited transport capacity and very low in the high order channels with high transport capacity [45]. Observations of post-fire sediment transport in a similar watershed in Wyoming suggest transport of fine sediments in suspension should be very efficient in high order channels even during base flow conditions [71]. These trends are approximated in our model by assigning cSDRs of $0.75,0.80,0.85$ and 0.95 per $10 \mathrm{~km}$ of stream length to $1 \mathrm{st}$, 2nd, $3 \mathrm{rd}$, and 4th or higher-order streams, respectively. Sediment retention in lakes and reservoirs was accounted for by assigning as a cSDR of 0.05 to the terminal flowline in each waterbody. The annual mass of fire-related sediment (Mg) delivered to the water diversion (TD) was calculated as the sum of sediment delivered to streams for all upstream catchments multiplied by the product of cSDRs for the intervening flowlines (Equation (4)).

$$
\mathrm{TD}=\operatorname{SUM}\left(\mathrm{TS}_{\mathrm{j}} \times\left[\operatorname{PRODUCT}\left(\mathrm{CSDR}_{\mathrm{k}}\right) \mid \mathrm{k}=1 \text { to } \mathrm{k}=\mathrm{P}\right]\right) \mid \mathrm{j}=1 \text { to } \mathrm{j}=\mathrm{O},
$$

The subscript $j$ is the index for the $\mathrm{O}$ upstream catchments and the subscript $\mathrm{k}$ is the index for the $P$ intervening flowlines between catchment $\mathrm{j}$ and the pipeline diversion.

\subsection{Water Supply Impacts}

The first metric of water supply impact is the total wildfire related sediment delivered to the diversion $(\mathrm{Mg})$. The second metric is the per-fire average post-storm suspended sediment concentration (SSC). Wilson et al. [66] found that a threshold rainfall intensity of $7 \mathrm{~mm} \mathrm{~h}^{-1}$ best predicts when post-fire hillslope erosion will occur in this region. This intensity is exceeded on average four times per year in the study watershed. We make the simplifying assumption that the first-year post-fire sediment load from the coupled erosion and sediment transport model is divided equally among four storms. We estimate that $35 \%$ of the hillslope erosion predicted by RUSLE is part of the fine-grained inorganic and organic components that contribute to suspended sediment based on observations of soil particle sizes generated from post-fire hillslope erosion and transported in suspension after summer thunderstorms in the region [71,72]. Post-fire water quality is usually degraded for short periods (hours to days) following rainstorms in this region [48,73], so we calculate post-storm suspended sediment concentrations using the average storm load of fine sediment and the daily flow volume past the diversion point, which averages $1.48 \times 10^{9} \mathrm{~L}$ per day for the May to October period (gage-adjusted estimates from [63]). Suspended sediment concentration is rarely monitored directly, so limits for treatment are more commonly expressed in turbidity. For this analysis, we use the high end of 100 Nephelometric Turbidity Units (NTU) reported in the literature [15,74] to be conservative in our judgement of exceeding limits for treatment. A conversion equation (Equation (5)) developed from 
post-fire monitoring of the Fourmile Canyon Fire was used to predict turbidity (NTU) from SSC $\left(\mathrm{mg} \mathrm{L}^{-1}\right)$ [15].

$$
\mathrm{NTU}=(\mathrm{SSC}-2.84) / 1.166,
$$

\subsection{Containment Effectiveness Evaluation and Prioritization}

To quantify the effectiveness of containment, we focused on the difference between the total water impact measures with and without containment including watershed area burned, sediment delivered to the diversion, and number of turbidity threshold exceedances. The difference between impact measures for the uncontained and contained scenarios is the avoided transmitted risk [36]. Total sediment load is a continuous value whereas turbidity exceedance is a binary outcome. Water quality degradation was only considered transmitted when the outcome changed from below 100 NTU for within POD burning to above 100 NTU for the entire fire footprint. To prioritize improvements along the potential control lines that bound PODs, we calculated risk transmission across the POD edges based on their proportional engagement with the fires that originate in their respective PODs; that is, the outcomes associated with fire spreading to the surrounding landscape were divided among the lines based on their intersected length. It is anticipated that the primary mitigation action would be fuels reduction along the control lines, so transmission risk was normalized by length to compare the relative benefit of hardening control lines.

\section{Results}

\subsection{Fire Occurrence}

Historical fire ignitions from the FOD [56] were concentrated in the lower and middle portions of the focal watershed and along the southern boundary of the study area (Figure 3a) reflecting both variation in fire season length and human use of the landscape. The 5000 wildfires simulated with RANDIG ranged in size from 0.09 to 20,868 ha with a mean of 1961 ha and a median of 1469 ha. We selected the 3040 fires that burned at least part of the focal watershed for further analysis. Their size distribution did not vary substantially from that of the full simulation set. The excluded fires either did not grow large enough to intercept the focal watershed, or the predominant wind direction caused them to spread away from it. The middle and lower portions of the watershed are predicted to burn most frequently due to both the greater ignition density and the presence of fuel types that promote faster spread (Figure 3b). The high elevations in the western half of the study area are predicted to burn infrequently due to low ignition density and sparse fuels. The southeast corner of the study area near the water diversion has low burn probability because the fuels have not yet recovered from a recent wildfire.

\subsection{Fire Behavior and Severity}

Crown fire activity is predicted to vary across the watershed due to differences in fuels and topography (Figure 4a). A notable portion of the alpine and some recently burned areas are mapped as non-burnable cover types (13.7\%). Surface, passive crown, and active crown fire are predicted on $25.9 \%, 39.3 \%$, and $21.1 \%$ of the watershed area respectively, which we use as proxies for low, moderate, and high burn severity. This translates to predictions of low severity effects in grass and shrub fuel types and moderate or high severity effects in most forests. High severity effects are most common in forests with high horizontal and vertical continuity on steep slopes. Our prediction that approximately $60 \%$ of the watershed should burn at moderate or high severity is in line with the observed severity of recent large wildfires in Colorado [75]. 
(a) Historical ignition density

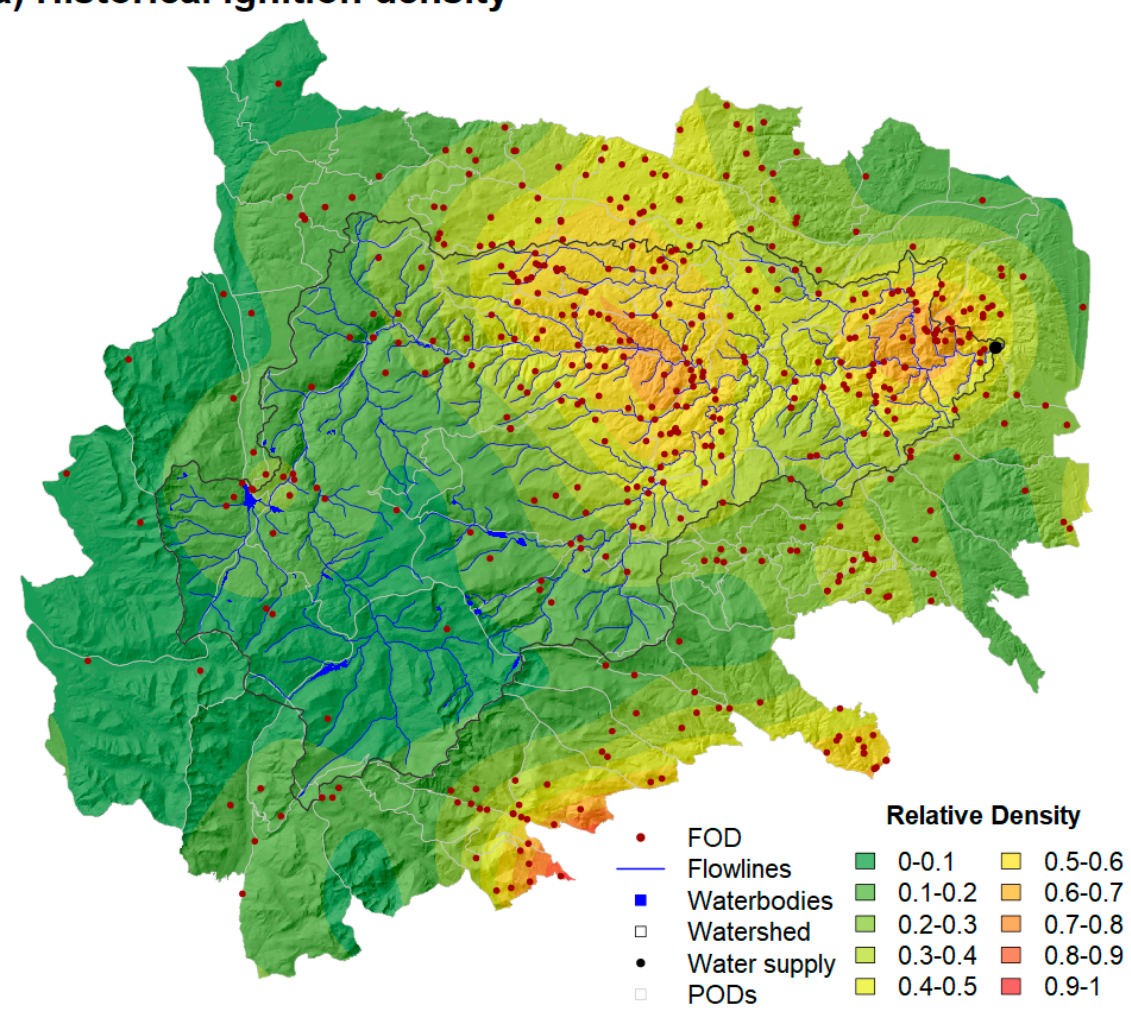

(b) Modeled burn probability

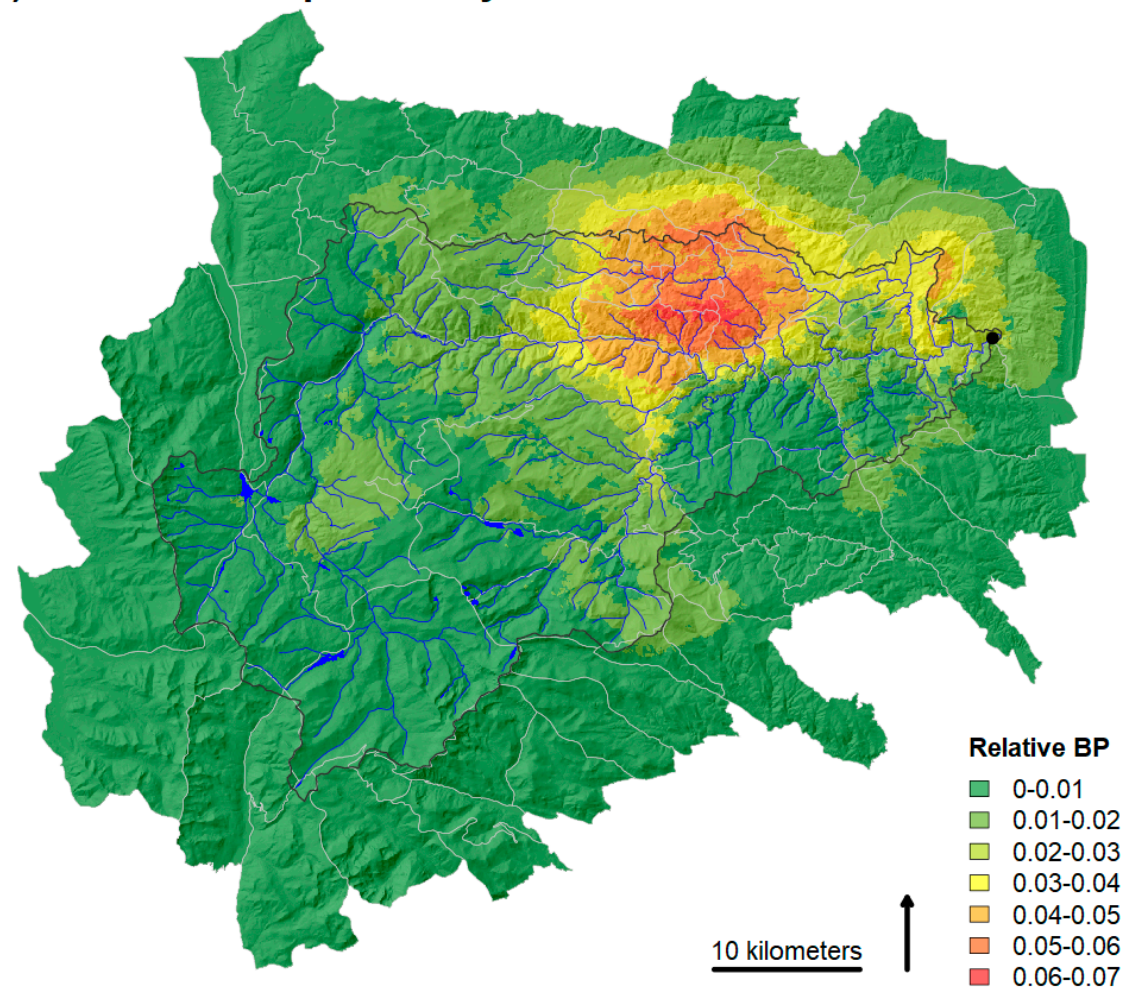

Figure 3. (a) Fire Occurrence Database (FOD) records of historical ignitions and interpolated surface of relative ignition density used in the RANDIG simulations. (b) Burn probability from the simulated fires that intercept the study watershed. 
(a) Burn severity

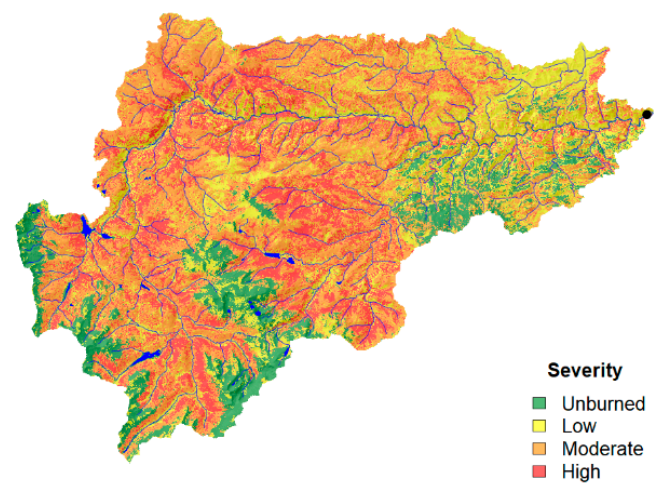

(c) Sediment transport

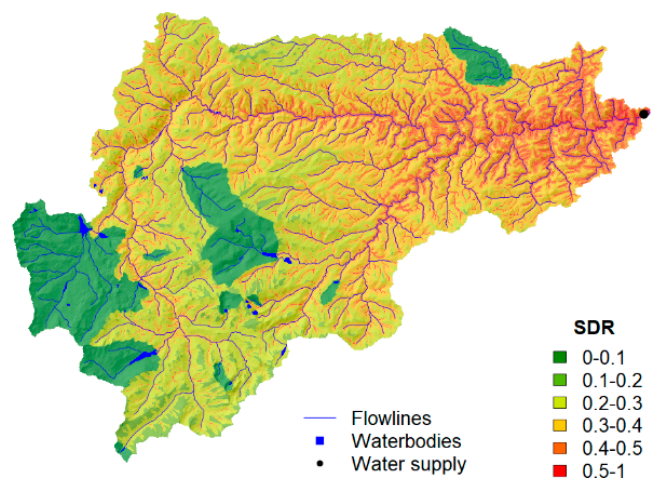

(b) Erosion

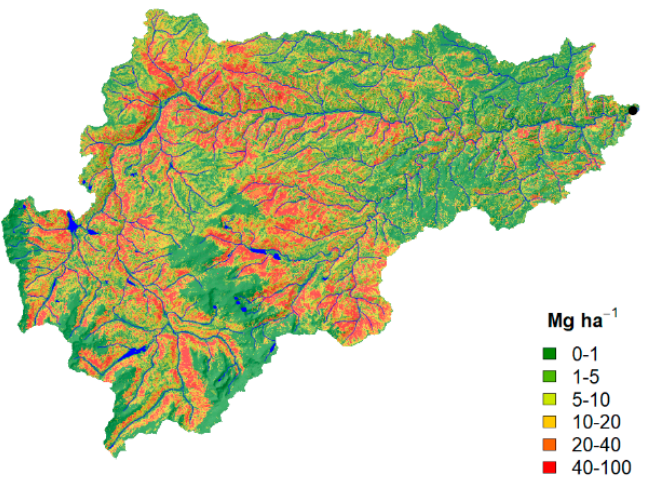

(d) Delivered sediment

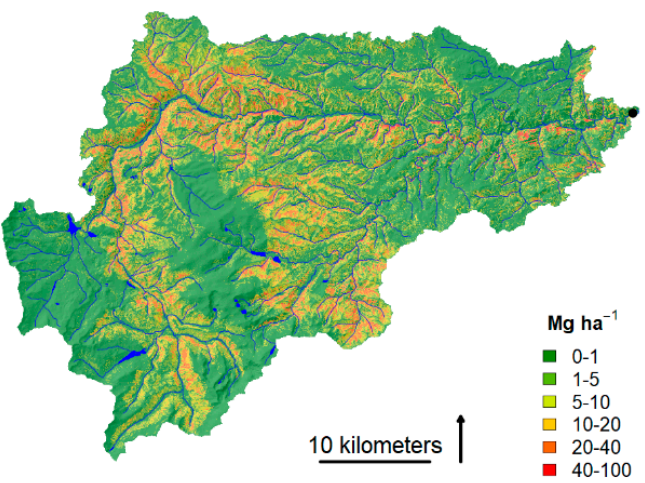

Figure 4. (a) Predicted burn severity using crown fire activity categories of surface, passive crown, and active crown fire as proxies for low, moderate, and high severity fire. (b) Predicted post-fire erosion with 2-year rainfall erosivity. (c) Combined Sediment Delivery Ratio (SDR) accounting for both hillslope and channel transport. (d) Predicted sediment delivery to the water supply diversion with 2-year rainfall erosivity.

\subsection{Watershed Response}

Like burn severity, the magnitudes of post-fire erosion and sediment transport vary widely across the watershed owing to variation in topography, soils, and proximity to the diversion. Figure 4 illustrates this for the 2-year rainfall erosivity. The greatest sediment hazard is associated with steep terrain near the major channels that is predicted to burn at moderate or high severity. Post-fire erosion and sediment transport potential is generally low in the flatter terrain in the northeast quadrant of the watershed, the high mountains above major waterbodies, and the recently burned areas. The spatial distribution of sediment hazard is similar for 10-year and 100-year rainfall erosivity, but the absolute magnitude increases considerably. Table 2 summarizes the distribution of predicted erosion, sediment delivery to streams, and sediment delivery to the diversion for the 3040 simulated wildfires that burned in the watershed. The predicted mean post-fire gross erosion for the simulated wildfires is 12.3, 20.4, and $46.4 \mathrm{Mg} \mathrm{ha}^{-1}$ for the 2, 10, and 100-year rainfall erosivity, respectively. Much of this sediment should be retained in the watershed, especially where waterbodies interrupt sediment transport (Figure 4c), so delivery to the diversion averages only $4.2,7.0$, and $15.9 \mathrm{Mg} \mathrm{ha}^{-1}$ for the 2, 10, and 100-year rainfall erosivity, respectively. 
Table 2. Summary statistics of first-year post fire erosion, sediment delivery to streams, and sediment delivery to the water supply diversion (div.) in $\mathrm{Mg} \mathrm{ha}^{-1}$ by rainfall erosivity for the simulated wildfires that burned into the watershed. These are total sediment yields including the coarse and fine fractions.

\begin{tabular}{|c|c|c|c|c|c|c|c|c|c|}
\hline \multirow[b]{2}{*}{ Statistic } & \multicolumn{3}{|c|}{ 2-Year Rainfall Erosivity } & \multicolumn{3}{|c|}{ 10-Year Rainfall Erosivity } & \multicolumn{3}{|c|}{ 100-Year Rainfall Erosivity } \\
\hline & Erosion & To Streams & To div. & Erosion & To Streams & To div. & Erosion & To Streams & To div. \\
\hline Lower decile & 2.0 & 1.0 & 0.4 & 4.3 & 2.1 & 0.9 & 18.5 & 9.1 & 4.3 \\
\hline $\begin{array}{c}\text { Lower } \\
\text { quartile }\end{array}$ & 5.0 & 2.6 & 1.6 & 9.8 & 5.0 & 3.2 & 32.3 & 16.5 & 11.0 \\
\hline Median & 9.0 & 4.7 & 3.3 & 16.5 & 8.6 & 6.2 & 45.2 & 23.4 & 16.8 \\
\hline Mean & 12.3 & 6.2 & 4.2 & 20.4 & 10.3 & 7.0 & 46.4 & 23.4 & 15.9 \\
\hline $\begin{array}{c}\text { Upper } \\
\text { quartile }\end{array}$ & 16.8 & 8.6 & 6.0 & 28.1 & 14.3 & 9.9 & 60.8 & 30.7 & 21.5 \\
\hline Upper decile & 27.7 & 13.7 & 8.7 & 42.9 & 20.9 & 13.6 & 75.3 & 36.8 & 24.7 \\
\hline
\end{tabular}

\subsection{Avoided Watershed Area Burned}

For improved containment at POD boundaries to avoid water supply impacts, the target fires must leave the POD of origin under unmanaged conditions. Of the 3040 simulated wildfires that burned at least part of the focal watershed, 2351 of them (77.3\%) burned at least some area outside the origin POD. Fires occasionally burned more than ten PODs, but of the fires that burned more than one POD, most burned between two and five PODs (77.9\%). This suggests that most fire transmission during the initial burn period is between a POD and its adjacent neighbors, but some rare events may burn across multiple POD boundaries.

Containing all fires within their POD of origin would reduce the average watershed area burned from 1361 to 562 ha per fire, a 58.7\% reduction (Table 3). The distributions of watershed area burned for the contained and uncontained scenarios are shown in Figure 5a. Containing large fires has the greatest potential to avoid watershed area burned; the 1396 fires that burned more than 1000 ha account for $93.8 \%$ of the avoided area burned. Containment in the POD of origin would eliminate fires that burn more than 10,000 ha in the watershed, which numbered $26(0.9 \%)$ in the uncontained scenario. The percentage of fires burning greater than 5000 ha would be reduced from 4.0 to 0.2 . Watershed area burned by fires that originate from PODs that are wholly or mostly outside the watershed should be reduced to negligible levels under the containment scenario, but these PODs account for only a small fraction of area burned when fires are allowed to grow freely (Figure 6a). Most fires start in the central and eastern portion of the watershed (Figure 3 ) and the predominant west winds means that PODs in the lower 2/3rds of the watershed are the source of fires that burn the greatest area (Figure 6a). All else equal, larger PODs are larger sources of fire because they have more ignitions. Containment reduced watershed area burned from fires that ignited in 61 of the 70 PODs, but some of the largest PODs still have substantial watershed area burned with containment (Figure 6a) because fires have room to grow large before encountering a potential control feature. 
Table 3. Summary of water supply impacts across all fires by containment scenario and rainfall erosivity. A turbidity threshold of 100 NTU was used to compute the number of exceedances.

\begin{tabular}{|c|c|c|c|c|}
\hline \multicolumn{5}{|c|}{ Watershed Area Burned (Mean ha per Fire) } \\
\hline & Self-burning & Total & Avoided & Avoided (\%) \\
\hline & 562 & 1361 & 799 & 58.7 \\
\hline \multicolumn{5}{|c|}{ Sediment to Diversion (Mean Mg per Fire) } \\
\hline Rainfall Erosivity & Self-Burning & Total & Avoided & Avoided (\%) \\
\hline 2-year & 3031 & 6115 & 3085 & 50.4 \\
\hline 10-year & 4904 & 10,188 & 5284 & 51.9 \\
\hline 100-year & 10,411 & 23,273 & 12,863 & 55.3 \\
\hline \multicolumn{5}{|c|}{ Turbidity Exceedances (Count of Fires) } \\
\hline Rainfall Erosivity & Self-Burning & Total & Avoided & Avoided (\%) \\
\hline 2-year & 1110 & 1668 & 558 & 33.5 \\
\hline 10-year & 1503 & 1910 & 407 & 21.3 \\
\hline 100-year & 1922 & 2210 & 288 & 13.0 \\
\hline
\end{tabular}
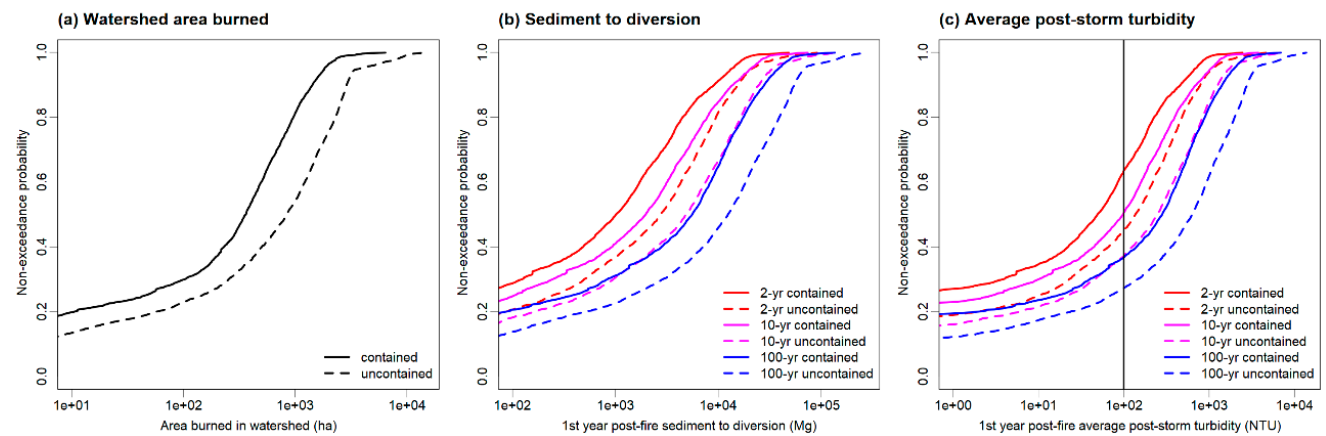

Figure 5. Summary of containment effects on distribution of fire-level indicators of water supply risk by rainfall erosivity including: (a) watershed area burned, (b) first-year post-fire sediment to the diversion, and (c) first-year post-fire average post-storm turbidity (vertical black line marks the 100 NTU threshold for treatment).

\subsection{Avoided Sediment}

Containment reduced the total sediment load to the pipeline diversion by $50.4-55.3 \%$ depending on rainfall erosivity from an average of 6.1-23.2 thousand $\mathrm{Mg}$ per fire to an average of 3.1-10.4 thousand $\mathrm{Mg}$ per fire (Table 3). The distributions of sediment delivered to the diversion for the contained and uncontained scenarios are shown in Figure $5 \mathrm{~b}$. Sediment loads vary across several orders of magnitude due to differences in fire size, erosion and sediment transport potential, and post-fire rainfall. The effect of containment on sediment load is roughly equivalent to reducing rainfall erosivity one level (Figure $5 b$ ). The spatial distribution of sediment source risk is similar to that of watershed area burned (Figure 6b). PODs that are partially or wholly outside the watershed are a minimal risk to water supplies after containment, but fire activity in the larger PODs situated in the middle of the watershed is still expected to produce large sediment loads. 
(a) Watershed area burned

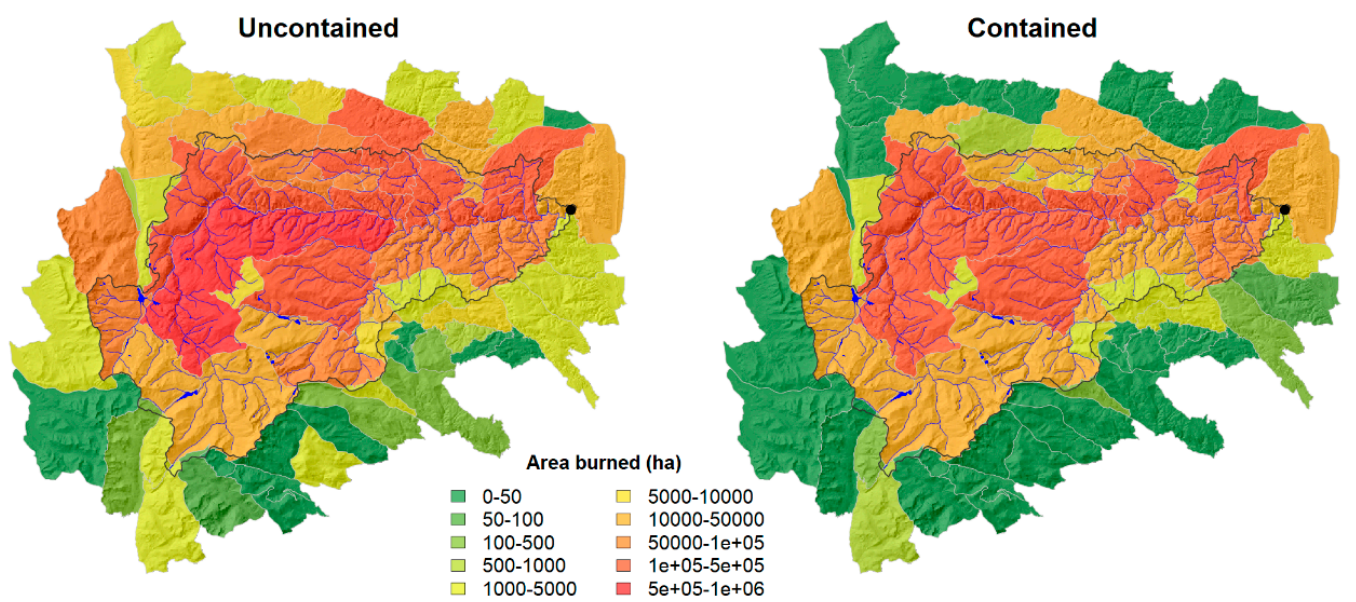

(b) Sediment to diversion

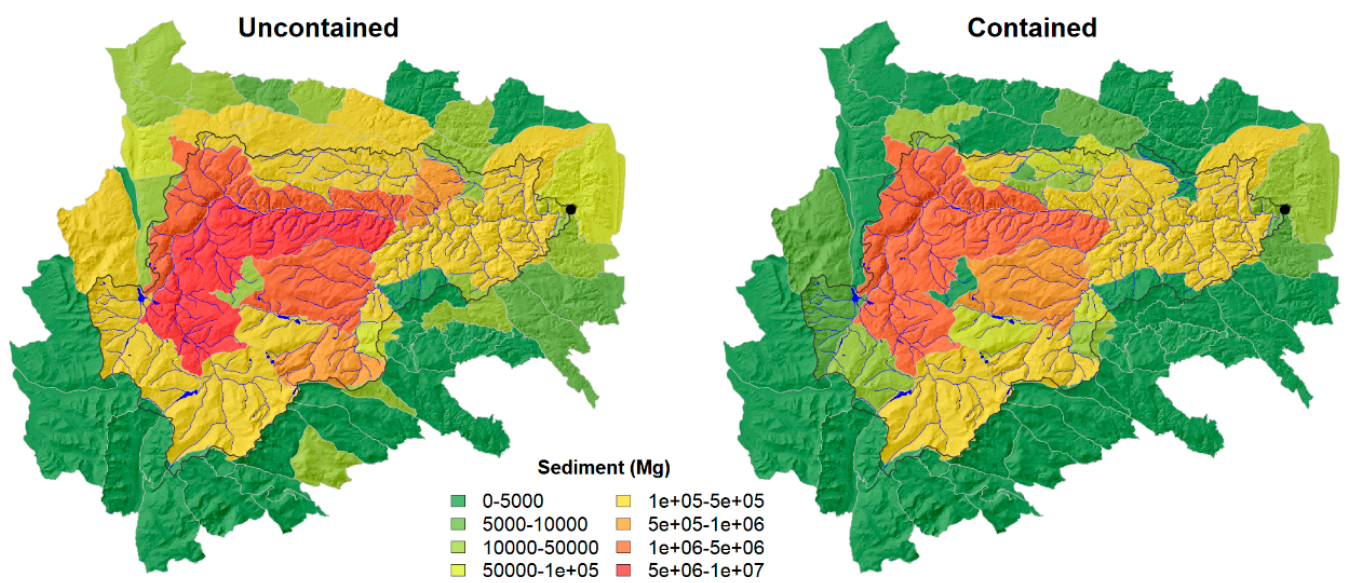

(c) Turbidity exceedances
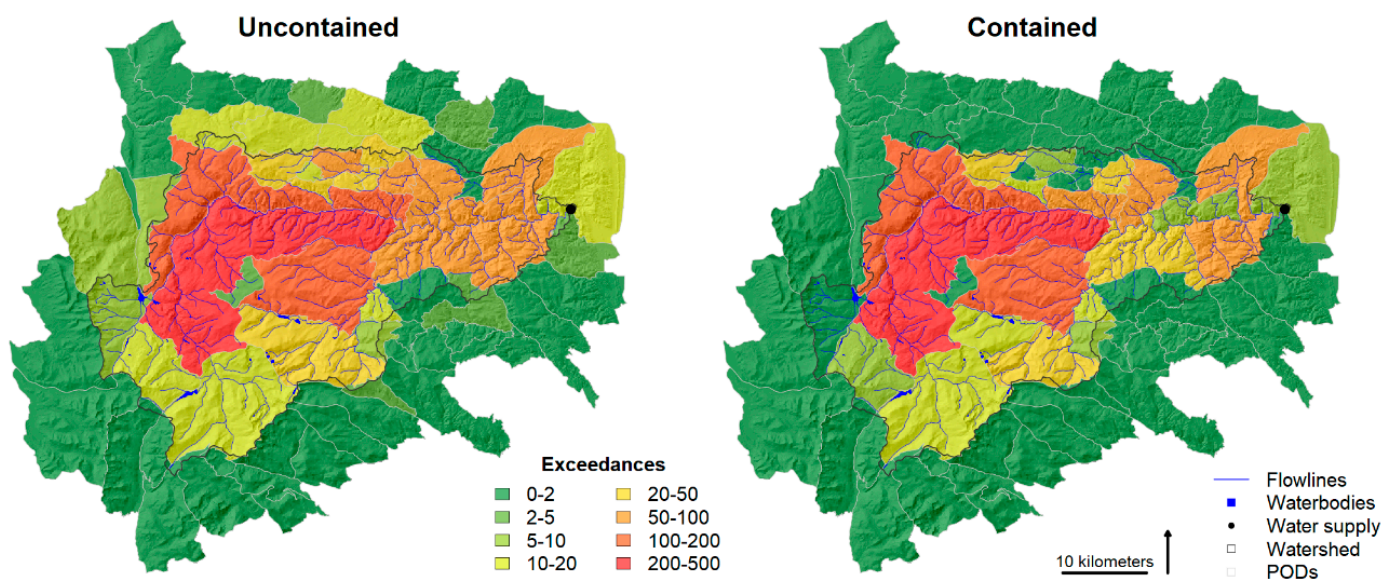

Figure 6. Spatial summary of containment effects on distribution of POD-level indicators of water supply risk for the 2-year rainfall erosivity including: (a) watershed area burned, (b) first-year post-fire sediment to the diversion, and (c) frequency of turbidity exceedances for fires that originate within each POD. 


\subsection{Avoided Water Quality Degradation}

Containment effects on water quality degradation were less substantial than for watershed area burned and total sediment to the diversion (Table 3; Figure 5c); turbidity exceedances were reduced by $33.5,21.3$, and 13.0 percent for the 2, 10, and 100-year rainfall erosivity, respectively. With containment, $36.5,49.4$, and 63.2 percent of fires are predicted to exceed the 100 NTU threshold for the 2, 10, and 100-year rainfall erosivity, respectively. Most fires that caused turbidity to exceed limits for treatment originated in the large PODs in the middle of the watershed (Figure 6c). The three PODs with the most turbidity exceedances are all larger than 10,000 ha. Containment only reduced the number of turbidity exceedances from these PODs from 640 to 568 (an 11.3\% reduction) for the 2-year rainfall erosivity, and containment offered almost no mitigation benefit (1.0\% fewer exceedances) for these PODs under the most extreme rainfall scenario. In contrast, containment reduced turbidity exceedances by more than $50 \%$ in 33 of the 70 PODs under median rainfall conditions. These PODs range in size from 502 to 14,153 ha with a mean of 3548 ha. Many of these PODs are mostly or wholly outside the watershed, but some are smaller PODs inside the watershed.

\subsection{Prioritizing POD Network Improvements}

The limited effect of containment on turbidity exceedances highlights the need to break up the three large PODs with high source risk in the middle of the watershed (Figure 6c). These three PODs are also the top priorities for further compartmentalization based on watershed area burned and total sediment load from self-burning. With containment, an additional eight PODs were the source of 20 or more turbidity exceedances under median rainfall conditions. Cumulatively, these top 11 PODs account for $91.4 \%$ of the fires that degraded water quality in the contained scenario, so efforts to further reduce fire sizes in these PODs should have high benefit.

Prioritizing improvements along the potential control lines that bound PODs can be informed with measures of risk transmission (Figure 7). Total sediment to the diversion was transmitted at the highest rates along POD edges in the middle portion of the watershed (Figure 7a) where there is high potential for fires to spread into erosion prone terrain near the diversion (Figures $3 \mathrm{~b}$ and 4 ). In contrast, transmitted water quality degradation was more concentrated along the edges associated with the smaller PODs in the north central portion of the watershed (Figure 7b). Transmission risk was also high for several control lines in the eastern half of the watershed that are nearly perpendicular to the dominant wind direction. Mitigation priorities differed depending on which metric of transmission risk was used (Figures 7 and 8). The two metrics both identify a similar order of priorities (Spearman's $\rho=0.89$ ) but they have moderate disagreement about the magnitudes of potential risk mitigation (Pearson's R $=0.71$ ), especially for the highest-ranking edges (Figure 8). Most notably, few of the POD edges associated with the three large PODs that are the source of most turbidity exceedances (Figure 6c) are high priorities for mitigation because containment at these locations infrequently changes the water quality outcome despite the potential to avoid large quantities of sediment. 
(a) Sediment to diversion per $\mathrm{km}$

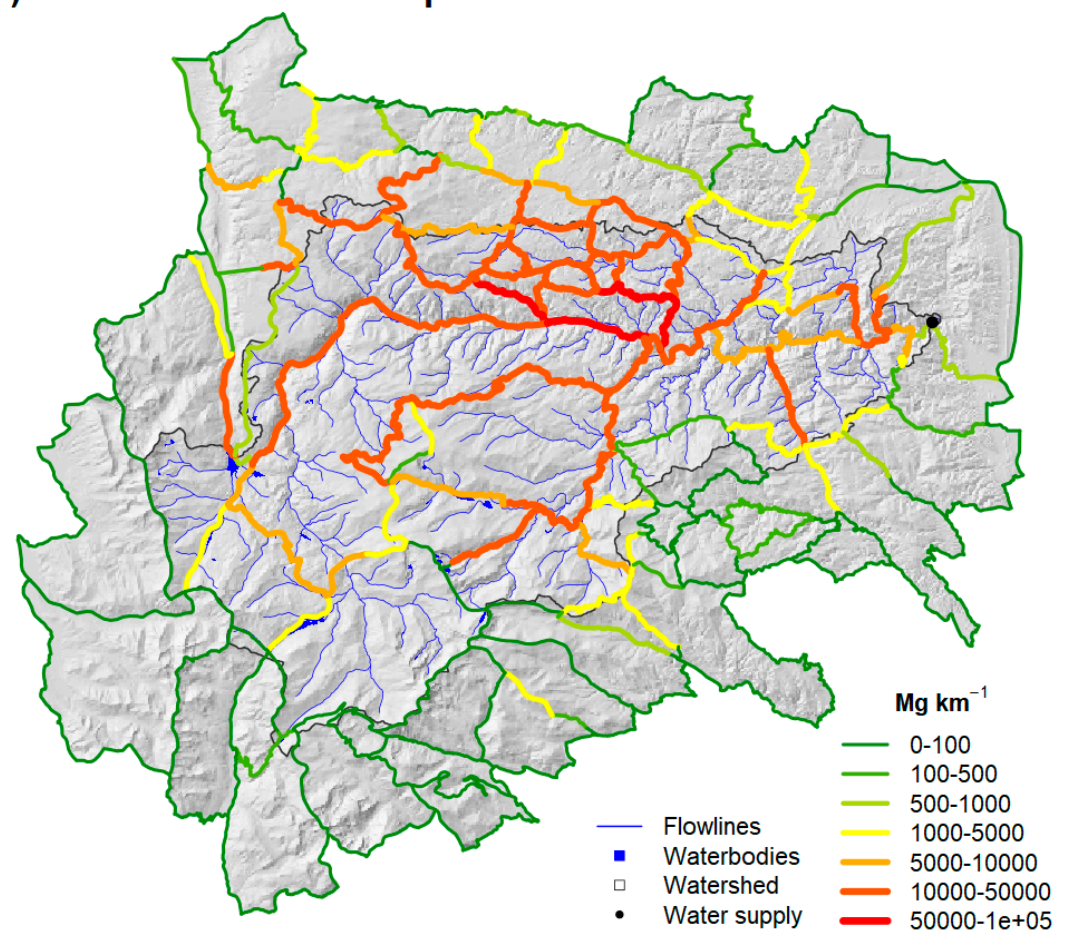

(b) Turbidity exceedances per km

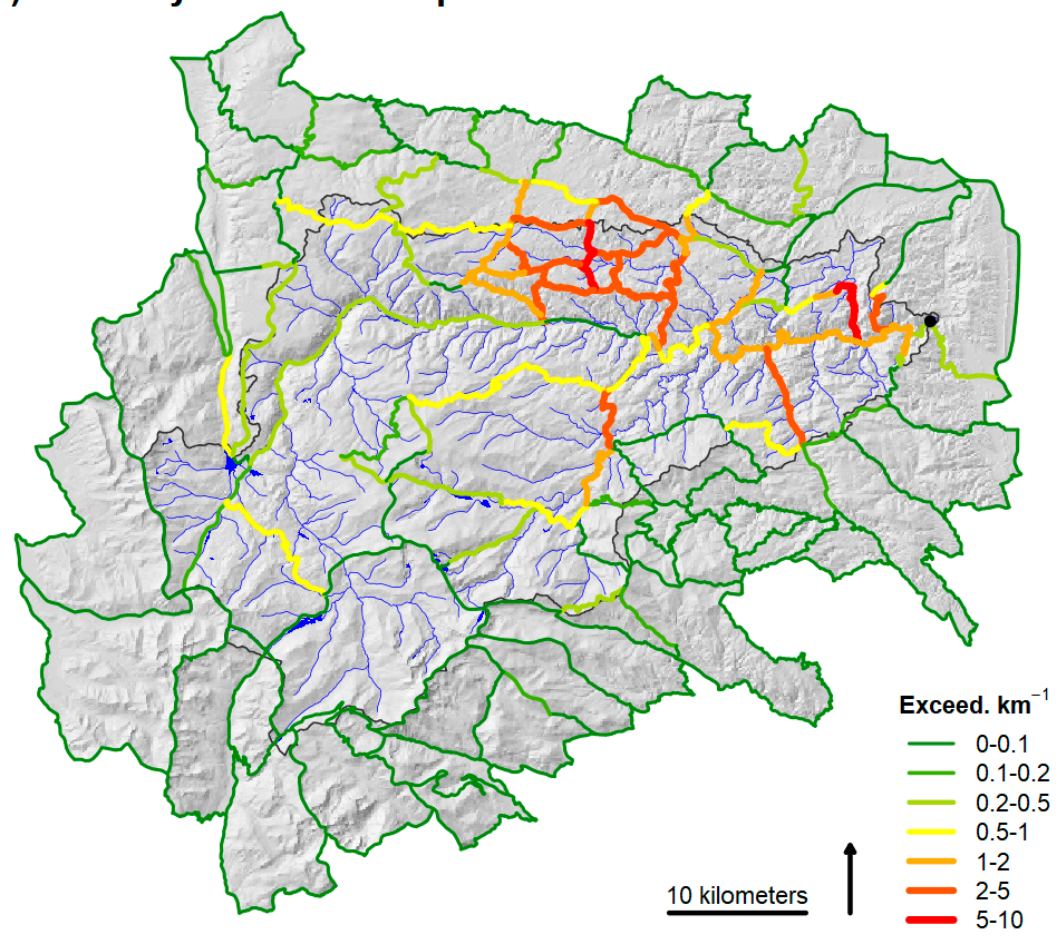

Figure 7. Total transmitted risk for all fires from (a) sediment to diversion and (b) turbidity exceedances normalized to edge length in kilometers for 2-year rainfall erosivity. 


\section{Edge Transmission Risk Comparison}

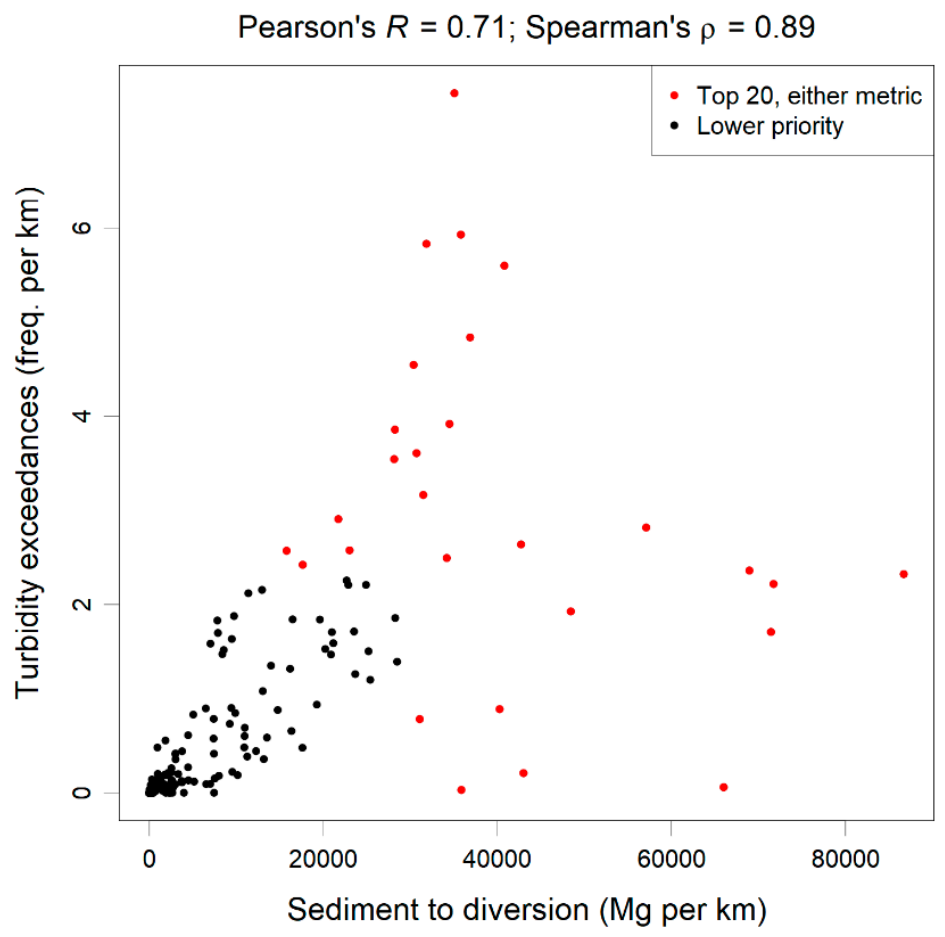

Figure 8. Edge transmission risk comparison for 2-year rainfall erosivity. Edges ranked in the top 20 using either metric are colored red.

\section{Discussion}

This proof of concept analysis demonstrates the potential for improved early containment of large fires to lower watershed area burned by $58.7 \%$ and to reduce risk to source water between $13.0 \%$ and $55.3 \%$ depending on impact metric considered. Proportional reductions in total sediment load to the diversion ranged between $50.4 \%$ and $55.3 \%$, but the potential to avoid exceeding turbidity limits for treatment was notably lower-varying between $33.5 \%$ and $13.0 \%$ reduction for the 2- and 100-year rainfall erosivity, respectively (Table 3). The contrasting response of our water impact metrics to increasing rainfall erosivity (Table 3) reveals that avoiding large quantities of sediment may not translate to avoiding degraded water quality if the residual sediment load is still large. The sources of water supply risk and potential mitigation benefits of fire containment varied widely across the POD network (Figure 6) suggesting the potential to further improve mitigation effectiveness with targeted divisions to reduce the size of PODs with high risk from self-burning and fuels reduction to improve containment probability along high transmission boundaries (Figure 7).

Our analysis built on previous studies of wildfire-water supply risk and wildfire risk transmission to estimate the avoided water supply impacts from improved fire containment within pre-identified PODs. Omi [18] approached this issue from the related perspective of fuel break construction and maintenance in California using estimates of avoided area burned and a relative damage index to value fuel break benefits. Monte Carlo wildfire simulation and watershed effects analyses capture similar information on exposure and impacts with the added benefit of associating fire outcomes with their ignition locations and final extents [32,33]. A recent effort to zone the study landscape into PODs provided the operationally relevant fire containers used to estimate avoided water supply impacts using risk transmission methods [35,36] as suggested by Davis [76] to estimate the area saved from burning after encountering a control feature. The avoided area burned and sediment load measures we modeled are similar to the impact metrics used to value the benefit of containment in previous studies, but our evaluation of water quality degradation provided a unique opportunity to evaluate whether the size and spatial arrangement of the PODs are appropriate to mitigate a scale-dependent risk. 
Our results suggest POD-based containment could meaningfully reduce risk of exceeding turbidity limits for treatment (Table 3), but the large percentage of unmitigated risk implies that the containment network could be more effective with smaller PODs.

Our estimates of avoided impacts are premised on the simplifying assumption that all fires are contained within their POD of origin, which is likely realistic for many of our modeled fires but optimistic for the most extreme fires in the region $[35,46]$. We chose not to address the probability of containment in this study because existing models focus on characteristics of the control features, surrounding fuels and topography, and fire behavior $[30,77,78]$ but do not explicitly consider the effects of suppression [79]. Managers in this landscape primarily identified roads as control features because they aid firefighter access [29] and suppression firing [51]. It is also anticipated that proactively identifying control features and response strategies will lead to timely and well-coordinated tactics that increase the probability of containment. For example, extensive pre-season planning has been credited with improving the strategic use of suppression firing and aerial retardant drops to contain fire in PODs during extreme weather [80]. We did not account for suppression firing in this study, which can sometimes substantially increase area burned [81] and thus would dampen the contrast between our containment scenarios. However, managers ideally use backing fire to minimize adverse effects [80]. Improved modeling of suppression actions and effects would help to refine our estimates of risk mitigation.

The post-fire erosion and sediment transport modeling used here has several limitations that are important to acknowledge. First, the linked fire and erosion model system (Figure 1) is subject to multiple data, model, and model linkage uncertainties that have potential for prediction error as discussed extensively in previous publications $[24,25]$. Recent work has shown that water quality at the basin scale is sometimes minimally impacted despite modeled increases in hillslope erosion [82], emphasizing the need to test and refine erosion and sediment transport models with empirical observations at multiple scales [83]. Most of our predicted first-year post-fire hillslope erosion yields for the 2-year and 10-year rainfall erosivity scenarios (Table 2) are close to the study-wide means of 9.5-22.2 $\mathrm{Mg} \mathrm{ha}^{-1}$ and the range of individual hillslope observations of $0.1-38.2 \mathrm{Mg} \mathrm{ha}^{-1}$ from previous fires in the region exposed to moderate rainfall $[11,17,47,84]$. Many of these studies had hillslope sediment fences fill and overtop, so the reported yields are usually interpreted as a lower bound estimate of the true erosion rate. For the 100-year rainfall erosivity, only the top decile of modeled fires exceed the $72 \mathrm{Mg} \mathrm{ha}^{-1}$ of rill and interrill erosion reported in the first year after the Buffalo Creek Fire in response to similarly extreme rainfall (converted from volume estimates of [45] using bulk density of $1.6 \mathrm{Mg} \mathrm{m}^{-3}$ ). Despite doubling the efficiency of hillslope transport in this study, only the net sediment delivery to streams for the upper decile of fires with 10-year rainfall erosivity and the upper half of fires with 100-year rainfall erosivity (Table 2) approach the small catchment sediment yields of 22.0-38.6 $\mathrm{Mg} \mathrm{ha}^{-1}$ observed in the first two years after the Hayman Fire $[85,86]$. This seems reasonable given the larger size of most catchments in this study. After our rough calibration, our combined hillslope and channel SDR values (Figure 4c) are close to SDR values estimated with similar travel time methods $[87,88]$. None of the simulated fires at any rainfall level (Table 2) are predicted to deliver sediment to the diversion at a rate close to the whole watershed sediment yield of $52.5 \mathrm{Mg} \mathrm{ha}^{-1}$ for the first year of the Buffalo Creek Fire [45], likely because we did not account for channel erosion.

Our water degradation analysis also layers on additional assumptions that the annual suspended sediment load is evenly divided among the annual average of four sediment-generating storms and the storm sediment load is evenly mixed in the average daily flow volume of the river during the thunderstorm season. Despite these approximations, the resulting turbidities-which averaged 309,516 , and 1181 NTU for the 2, 10, and 100-year rainfall erosivity, respectively-align well with common observations in the region of post-fire turbidities between 100 and 1000 NTU and occasional observations $>1000$ NTU $[15,48,89]$. The assumption that storm load is an equal division of annual load does not account for the substantial intra-annual variability in storm characteristics $[15,83,90]$, seasonal trends in runoff and erosion [91], nor the interannual variability in the frequency of storms 
with sufficient intensity to cause erosion $[34,66]$. Similarly, unaccounted for variability in daily flow volume should influence the vulnerability of the water source. Given these simplifications, we have more confidence in our contrasts of containment benefits across scenarios than we do in our absolute estimates of degradation risk. Our analysis also focused exclusively on the acute periods of severe water quality degradation after rainstorms in the first year after fire, so it is unclear if containing fires to smaller sizes will avoid elevated carbon, nitrogen, phosphorus, manganese, and suspended solids concentrations that may persist for years after fires in Colorado [15,89], increasing treatment complexity and cost and raising concerns about the formation of disinfection byproducts [74,92]. Similar water quality responses and treatment challenges have been observed after wildfires in Canada, Australia, and Europe $[12,13]$.

Despite uncertainties in the precise magnitude of risk reduction, improved containment appears promising compared to other mitigation strategies. We found that limiting fires to their POD of origin should reduce the total sediment load from wildfire between 50.4 and 55.3\% (Table 3). Previous assessments of landscape-scale fuel treatments in the western USA predict long-term sediment reduction of $19 \%$ [25] and up to 34\% reduction in sediment costs [24]. Salis et al. [93] project that treating $15 \%$ of a landscape in Sardinia, Italy would only reduce average sediment yield $4-12 \%$, but their treatment scenarios were not prioritized to avoid erosion. Based on the narrowest contrast in these figures (34\% for fuel treatment and $50.4 \%$ for containment), POD-based containment should compare favorably to landscape scale fuels reduction as long as the containment failure rate is less than $32 \%$. Furthermore, compartmentalizing fire in small units of the landscape has the potential to avoid disrupting multi-source water systems by limiting fire impacts to a single source. The benefit of containing individual wildfires should vary widely (Figure 5), as fire encounters with control features and associated impacts beyond the POD of origin depend strongly on where the fire ignites.

We also demonstrated how risk transmission metrics could inform improvements to the POD network, which should be relevant to fire, land, and water managers engaged in spatial fire planning. The small number of PODs with high risk from self-burning are high priorities for further compartmentalization, which could require improving firefighter access and/or reducing fuels. Fine scale analyses of risk factors and containment opportunities would benefit these efforts. If further divisions are not feasible or practical (e.g., because of wilderness or wildlife habitat concerns), these PODs could be candidates for fuels reduction with prescribed or managed fire. It is also valuable for water managers to identify areas that are not conducive to proactive risk mitigation, so they can plan how to best respond to the anticipated effects of future fires. As previously discussed, we did not estimate the probability of containing wildfire at POD boundaries and how containment probability would change with fuels reduction, but managers are interested in identifying potential control lines in need of improvement to support safe and effective fire response. Measures of transmission risk across the POD edges (Figure 7) highlight where these efforts should be targeted to maximize their benefit. However, priorities differed depending on the water supply effects measure used (Figure 8); most notably, there is greater potential to avoid degradation by improving containment probability around the smaller PODs. Further analyses are needed to evaluate if fuel conditions around these POD edges necessitate treatment for firefighting effectiveness and safety.

The style of Monte Carlo exposure and effects analyses we present should also be useful for evaluating fire protection strategies for other high value resources and assets that depend on the scale of disturbance. For example, most ecological concerns relate to the area and spatial pattern of high severity effects on vegetation and the resulting consequences for wildlife and reforestation by dispersal-limited species (e.g., [94-96]). If intolerable levels of fire exposure or effects can be defined for ecological values, similar methods could be used to assess the protection value of POD-based containment. Wildfire impacts to homes and other values in the wildland-urban interface (WUI) are almost always negative, but consequences often become disastrous when the area and assets affected by fire overwhelm firefighting resources [97]. Managers intuitively design smaller PODs in the WUI [2], but it has not been tested whether these PODs are appropriately sized to avert WUI disasters-i.e., 
whether asset exposure for most fires is below the fire protection capacity. Similarly, wildfire impacts to transportation networks may cross thresholds of concern for evacuation when traffic exceeds the capacity of the available routes. Explicitly defining performance objectives for these and other fire protection concerns could help to tailor POD size and spatial arrangement in future fire planning efforts.

\section{Conclusions}

Improved wildfire containment has potential to meaningfully reduce wildfire risk to water supplies, but these effects are scale dependent. In our test cases, approximately $75 \%$ of fires intersected potential control features and, if these fires were contained within their POD of origin, watershed area burned would be reduced by $58.7 \%$, total sediment load to the diversion would be reduced between 50.4 and $55.3 \%$, and water quality degradation beyond limits for treatment would be reduced between 13.0 and $33.5 \%$. Risk mitigation was higher for total sediment load than water quality degradation because containment did not always change water quality outcomes. Moreover, priorities to improve the network design by modifying the size of the PODs or improving containment probability along their edges differ depending on the effects measure used. This highlights the importance of properly defining water supply impacts for wildfire risk assessment and mitigation effectiveness studies. Similar analyses could be applied to other scale-dependent resources at risk of wildfire to inform containment network design.

Author Contributions: Conceptualization, B.M.G., Y.W. and M.P.T.; methodology, B.M.G.; software, B.M.G.; formal analysis, B.M.G.; investigation, B.M.G.; data curation, B.M.G.; writing-original draft preparation, B.M.G.; writing-review and editing, B.M.G., Y.W. and M.P.T.; visualization, B.M.G.; supervision, Y.W.; project administration, Y.W.; funding acquisition, Y.W. and M.P.T. All authors have read and agreed to the published version of the manuscript.

Funding: This research was funded by joint venture agreement 19-JV-11221636-170 between the USDA Forest Service Rocky Mountain Research Station and Colorado State University; cost share agreement number 17-CS-11021000-032 between the USDA Forest Service, Arapaho and Roosevelt National Forests and Pawnee National Grassland and the Colorado Forest Restoration Institute at Colorado State University; and agreement number 19-DG-11031600-062 between the USDA Forest Service, Southwestern Region and the Colorado Forest Restoration Institute at Colorado State University.

Acknowledgments: The authors thank Codie Wilson for sharing the rainfall data used in the analysis.

Conflicts of Interest: The authors declare no conflict of interest. The funders had no role in the design of the study; in the collection, analyses, or interpretation of data; in the writing of the manuscript, or in the decision to publish the results.

\section{References}

1. O'Connor, C.D.; Thompson, M.P.; Rodríquez y Silva, F. Getting ahead of the wildfire problem: Quantifying and mapping management challenges and opportunities. Geosciences 2016, 6, 35. [CrossRef]

2. Thompson, M.P.; Bowden, P.; Brough, A.; Scott, J.H.; Gilbertson-Day, J.; Taylor, A.; Anderson, J.; Haas, J.R. Application of wildfire risk assessment results to wildfire response planning in the Southern Sierra Nevada, California, USA. Forests 2016, 7, 64. [CrossRef]

3. Thompson, M.P.; MacGregor, D.G.; Dunn, C.J.; Calkin, D.E.; Phipps, J. Rethinking the wildland fire management system. J. For. 2018, 116, 382-390. [CrossRef]

4. Caggiano, M.D. Collaboratively Engaging Stakeholders to Develop Potential Operational Delineations; Report CFRI-1908; Colorado Forest Restoration Institute: Fort Collins, CO, USA, 2019.

5. Caggiano, M.D.; O'Connor, C.D.; Sack, R.B. Potential Operational Delineations and Northern New Mexico's 2019 Fire Season; Report CFRI-2002; Colorado Forest Restoration Institute: Fort Collins, CO, USA, 2019.

6. Greiner, M.; Kooistra, C.; Schultz, C. Pre-Season Planning for Wildland Fire Response: An Assessment of the US Forest Service's Potential Operational Delineations (PODs); Practitioner Paper \#05; Public Lands Policy Group at Colorado State University: Fort Collins, CO, USA, 2020.

7. Dunn, C.J.; O'Connor, C.D.; Abrams, J.; Thompson, M.P.; Calkin, D.E.; Johnston, J.D.; Stratton, R.; Gilbertson-Day, J. Wildfire risk science facilitates adaptation of fire-prone social-ecological systems to the new fire reality. Environ. Res. Lett. 2020, 15, 025001. [CrossRef] 
8. Stratton, R.D. The path to strategic wildland fire management planning. Wildfire Mag. 2020, $29,24-31$.

9. DeBano, L.F.; Neary, D.G.; Ffolliott, P.F. Soil physical processes. In Wildland Fire in Ecosystems: Effects of Fire on Soils and Water; Neary, D.G., Ryan, K.C., Eds.; General Technical Report RMRS-GTR-42; USDA Forest Service, Rocky Mountain Research Station: Ogden, UT, USA, 2005; Volume 4, pp. 29-51.

10. Shakesby, R.A.; Doerr, S.H. Wildfire as a hydrological and geomorphological agent. Earth Sci. Rev. 2006, 74, 269-307. [CrossRef]

11. Larsen, I.J.; MacDonald, L.H.; Brown, E.; Rough, D.; Welsh, M.J.; Pietraszek, J.H.; Libohova, Z.; Benavides-Solorio, J.D.; Schaffrath, K. Causes of post-fire runoff and erosion: Water repellency, cover, or soil sealing? Soil Sci. Soc. Am. J. 2009, 73, 1393-1407. [CrossRef]

12. Smith, H.G.; Sheridan, G.J.; Lane, P.N.J.; Nyman, P.; Haydon, S. Wildfire effects on water quality in forest catchments: A review with implications for water supply. J. Hydrol. 2011, 396, 170-192. [CrossRef]

13. Emelko, M.B.; Silins, U.; Bladon, K.D.; Stone, M. Implications of land disturbance on drinking water treatability in a changing climate: Demonstrating the need for "source water supply and protection" strategies. Water Res. 2011, 45, 461-472. [CrossRef]

14. Abraham, J.; Dowling, K.; Florentine, S. Risk of post-fire metal mobilization into surface water resources: A review. Sci. Total Environ. 2017, 599-600, 1740-1755. [CrossRef]

15. Murphy, S.F.; Writer, J.H.; McCleskey, R.B.; Martin, D.A. The role of precipitation type, intensity, and spatial distribution in source water quality after wildfire. Environ. Res. Lett. 2015, 10, 084007. [CrossRef]

16. Benavides-Solorio, J.D.; MacDonald, L.H. Measurement and prediction of post-fire erosion at the hillslope scale, Colorado Front Range. Int. J. Wildland Fire 2005, 14, 457-474. [CrossRef]

17. Schmeer, S.R.; Kampf, S.K.; MacDonald, L.H.; Hewitt, J.; Wilson, C. Empirical models of annual post-fire erosion on mulched and unmulched hillslopes. Catena 2018, 163, 276-287. [CrossRef]

18. Omi, P.N. Planning future fuelbreak strategies using mathematical modeling techniques. Environ. Manag. 1979, 3, 73-80. [CrossRef]

19. Thompson, M.P.; Scott, J.; Langowski, P.G.; Gilbertson-Day, J.W.; Haas, J.R.; Bowne, E.M. Assessing watershed-wildfire risks on national forest system lands in the Rocky Mountain region of the United States. Water 2013, 5, 945-971. [CrossRef]

20. Cannon, S.H.; Gartner, J.E.; Rupert, M.G.; Michael, J.A.; Rea, A.H.; Parrett, C. Predicting the probability and volume of post-wildfire debris flows in the intermountain western United States. Geol. Soc. Am. Bull. 2010, 122, 127-144. [CrossRef]

21. Miller, M.E.; MacDonald, L.H.; Robichaud, P.R.; Elliot, W.J. Predicting post-fire hillslope erosion in forest lands of the western United States. Int. J. Wildland Fire 2011, 20, 982-999. [CrossRef]

22. Miller, M.E.; Elliot, W.J.; Billmire, M.; Robichaud, P.R.; Endsley, K.A. Rapid-response tools and datasets for post-fire remediation: Linking remote sensing and process-based hydrological models. Int. J. Wildland Fire 2016, 25, 1061-1073. [CrossRef]

23. Sidman, G.; Guertin, D.P.; Goodrich, D.C.; Thoma, D.; Falk, D.; Burns, I.S. A coupled modelling approach to assess the effect of fuel treatments on post-wildfire runoff and erosion. Int. J. Wildland Fire 2016, 25, 351-362. [CrossRef]

24. Gannon, B.M.; Wei, Y.; MacDonald, L.H.; Kampf, S.K.; Jones, K.W.; Cannon, J.B.; Wolk, B.H.; Cheng, A.S.; Addington, R.N.; Thompson, M.P. Prioritising fuels reduction for water supply protection. Int. J. Wildland Fire 2019, 28, 785-803. [CrossRef]

25. Elliot, W.J.; Miller, M.E.; Enstice, N. Targeting forest management through fire and erosion modelling. Int. J. Wildland Fire 2016, 25, 876-887. [CrossRef]

26. Jones, K.W.; Cannon, J.B.; Saavedra, F.A.; Kampf, S.K.; Addington, R.N.; Cheng, A.S.; MacDonald, L.H.; Wilson, C.; Wolk, B. Return on investment from fuel treatments to reduce severe wildfire and erosion in a watershed investment program in Colorado. J. Environ. Manag. 2017, 198, 66-77. [CrossRef] [PubMed]

27. Thompson, M.P.; Liu, Z.; Wei, Y.; Caggiano, M.D. Analyzing wildfire suppression difficulty in relation to protection demand. In Environmental Risks; Mihai, F.-C., Grozavu, A., Eds.; IntechOpen Limited: London, UK, 2018; pp. 45-64. [CrossRef]

28. Wei, Y.; Thompson, M.P.; Haas, J.R.; Dillon, G.K.; O'Connor, C.D. Spatial optimization of operationally relevant large fire confine and point protection strategies: Model development and test cases. Can. J. For. Res. 2018, 48, 480-493. [CrossRef] 
29. Rodríguez y Silva, F.; Molina Martínez, J.R.; González-Cabán, A. A methodology for determining operational priorities for prevention and suppression of wildland fires. Int. J. Wildland Fire 2014, 23, 544-554. [CrossRef]

30. O'Connor, C.D.; Calkin, D.E.; Thompson, M.P. An empirical machine learning method for predicting potential fire control locations for pre-fire planning and operational fire management. Int. J. Wildland Fire 2017, 26, 587-597. [CrossRef]

31. Rodríguez y Silva, F.; O’Connor, K.; Thompson, M.P.; Molina Martínez, J.R.; Calkin, D.E. Modelling suppression difficulty: Current and future applications. Int. J. Wildland Fire 2020, in press. [CrossRef]

32. Thompson, M.P.; Gilbertson-Day, J.W.; Scott, J.H. Integrating pixel- and polygon-based approaches to wildfire risk assessment: Applications to a high-value watershed on the Pike and San Isabel National Forests, Colorado, USA. Environ. Model. Assess. 2016, 21, 1-15. [CrossRef]

33. Haas, J.R.; Thompson, M.; Tillery, A.; Scott, J.H. Capturing spatiotemporal variation in wildfires for improving post-wildfire debris-flow hazard assessments. In Natural Hazard Uncertainty Assessment: Modeling and Decision Support, Geophysical Monograph 223; Riley, K., Webley, P., Thompson, M., Eds.; John Wiley \& Sons: Hoboken, NJ, USA, 2017; pp. 301-317.

34. Gannon, B.M.; Wei, Y.; Thompson, M.P.; Scott, J.H.; Short, K.C. System analysis of wildfire-water supply risk in Colorado, U.S.A. with Monte Carlo wildfire and rainfall simulation. Risk Anal. 2020. in review.

35. Haas, J.R.; Calkin, D.E.; Thompson, M.P. Wildfire risk transmission in the Colorado Front Range, USA. Risk Anal. 2015, 35, 226-240. [CrossRef]

36. Ager, A.A.; Palaiologou, P.; Evers, C.R.; Day, M.A.; Barros, A.M.G. Assessing transboundary wildfire exposure in the southwestern United States. Risk Anal. 2018, 38, 2105-2127. [CrossRef]

37. Finney, M.A. The challenge of quantitative risk analysis for wildland fire. For. Ecol. Manag. 2005, 211, 97-108. [CrossRef]

38. Scott, J.H.; Thompson, M.P.; Calkin, D.E. A Wildfire Risk Assessment Framework for Land and Resource Management; General Technical Report RMRS-GTR-315; USDA Forest Service, Rocky Mountain Research Station: Fort Collins, CO, USA, 2013.

39. Finney, M.A. An overview of FlamMap fire modeling capabilities. In Proceedings of the Fuels Management-How to Measure Success Conference, Portland, OR, USA, 28-30 March 2006; Andrews, P.L., Butler, B.W., Eds.; Proceedings RMRS-P-41. USDA Forest Service, Rocky Mountain Research Station: Fort Collins, CO, USA, 2006; pp. 213-220.

40. Finney, M.A.; Brittain, S.; Seli, R.C.; McHugh, C.W.; Gangi, L. FlamMap: Fire Mapping and Analysis System, Version 5.0; USDA Forest Service, Rocky Mountain Research Station: Fort Collins, CO, USA, 2015. Available online: http://www.firelab.org/document/flammap-software (accessed on 1 November 2019).

41. Renard, K.G.; Foster, G.R.; Weesies, G.A.; McCool, D.K.; Yoder, D.C. Predicting Soil Erosion by Water: A Guide to Conservation Planning with the Revised Universal Soil Loss Equation (RUSLE); Handbook no. 703; USDA Agricultural Research Service Agricultural: Washington, DC, USA, 1997.

42. Wagenbrenner, J.W.; Robichaud, P.R. Post-fire bedload sediment delivery across spatial scales in the interior western United States. Earth Surf. Process. Landf. 2014, 39, 865-876. [CrossRef]

43. Frickel, D.G.; Shown, L.M.; Patton, P.C. An Evaluation of Hillslope and Channel Erosion Related to Oil-Shale Development in the Piceance Basin, North-Western Colorado; Colorado Department of Natural Resources, Colorado Water Resources Circular 30: Denver, CO, USA, 1975.

44. R Core Team. R: A Language and Environment for Statistical Computing, Version 3.5.3; R Foundation for Statistical Computing: Vienna, Austria, 2019. Available online: https://www.R-project.org/ (accessed on 1 May 2019).

45. Moody, J.A.; Martin, D.A. Initial hydrologic and geomorphic response following a wildfire in the Colorado Front Range. Earth Surf. Process. Landf. 2001, 26, 1049-1070. [CrossRef]

46. Graham, R.T. Hayman Fire Case Study; USDA Forest Service, Rocky Mountain Research Station, General Technical Report RMRS-GTR-114: Ogden, UT, USA, 2003.

47. Wagenbrenner, J.W.; MacDonald, L.H.; Rough, D. Effectiveness of three post-fire rehabilitation treatments in the Colorado Front Range. Hydrol. Process. 2006, 20, 2989-3006. [CrossRef]

48. Oropeza, J.; Heath, J. Effects of the 2012 Hewlett and High Park Wildfires on Water Quality of the Poudre River and Seaman Reservoir; City of Fort Collins Utilities Report: Fort Collins, CO, USA, 2013.

49. Moody, J.A.; Martin, D.A. Synthesis of sediment yields after wildland fire in different rainfall regimes in the western United States. Int. J. Wildland Fire 2009, 18, 96-115. [CrossRef] 
50. LANDFIRE. Fuel, Topography, Existing Vegetation Type, and Fuel Disturbance Layers, Version 1.4.0.; USDOI Geological Survey: Washington, DC, USA, 2016. Available online: http://landfire.cr.usgs.gov/viewer/ (accessed on 23 August 2016).

51. Price, O.; Bradstock, R. The effect of fuel age on the spread of fire in sclerophyll forest in the Sydney region of Australia. Int. J. Wildland Fire 2010, 19, 35-45. [CrossRef]

52. Narayanaraj, G.; Wimberly, M.C. Influences of forest roads on the spatial pattern of wildfire boundaries. Int. J. Wildland Fire 2011, 20, 792-803. [CrossRef]

53. Yocum, L.L.; Jenness, J.; Fulé, P.Z.; Thode, A.E. Previous fires and roads limit wildfire growth in Arizona and New Mexico, U.S.A. For. Ecol. Manag. 2019, 449, 117440. [CrossRef]

54. Scott, J.H.; Burgan, R.E. Standard Fire Behavior Fuel Models: A Comprehensive Set for Use with Rothermel's Surface Fire Spread Model; General Technical Report RMRS-GTR-153; USDA Forest Service, Rocky Mountain Research Station: Fort Collins, CO, USA, 2005.

55. Moriarty, K.; Cheng, A.S.; Hoffman, C.M.; Cottrell, S.P.; Alexander, M.E. Firefighter observations of "surprising" fire behavior in mountain pine beetle-attacked lodgepole pine forests. Fire 2019, 2, 34. [CrossRef]

56. Short, K.C. Spatial Wildfire Occurrence Data for the United States, 1992-2015, 4th ed; USDA Forest Service Research Data Archive: Fort Collins, CO, USA, 2017. [CrossRef]

57. ESRI. ArcGIS, Version 10.3; Environmental Systems Research Institute: Redlands, CA, USA, 2015. Available online: https://www.esri.com/en-us/home (accessed on 1 July 2017).

58. NWCG. Remote Automated Weather Station Data; National Wildfire Coordinating Group: Washington, DC, USA, 2018. Available online: https://fam.nwcg.gov/fam-web/weatherfirecd/index.htm (accessed on 6 June 2018).

59. Bradshaw, L.; McCormick, E. FireFamily Plus User's Guide, Version 2.0; General Technical Report RMRS-GTR-67WWW; USDA Forest Service, Rocky Mountain Research Station: Ogden, UT, USA, 2000.

60. Crosby, J.S.; Chandler, C.C. Get the most from your windspeed observation. Fire Control Notes 1966, $27,12-13$.

61. Scott, J.H.; Reinhardt, E.D. Assessing Crown Fire Potential by Linking Models of Surface and Crown Fire Behavior; General Technical Research Paper RMRS-RP-29; USDA Forest Service, Rocky Mountain Research Station: Fort Collins, CO, USA, 2001.

62. Tillery, A.C.; Haas, J.R.; Miller, L.W.; Scott, J.H.; Thompson, M.P. Potential Post-Wildfire Debris-Flow Hazards-A Pre-Wildfire Evaluation for the Sandia and Manzano Mountains and Surrounding Areas, Central New Mexico; Scientific Investigations Report 2014-5161; US Geological Survey: Albuquerque, NM, USA, 2014.

63. USEPA; USGS. National Hydrography Dataset Plus_-NHDPlus, Version 2.1; US Environmental Protection Agency and USDOI Geological Survey: Washington, DC, USA, 2012. Available online: http://www.horizonsystems.com/NHDPlus/index.php (accessed on 23 August 2016).

64. Theobald, D.M.; Merritt, D.M.; Norman, J.B. Assessment of Threats to Riparian Ecosystems in the Western U.S.; Report to the Western Environmental Threats Assessment Center by the USDA Stream Systems Technology Center and Colorado State University: Fort Collins, CO, USA, 2010.

65. Perica, S.; Martin, D.; Pavlovic, S.; Roy, I.; St. Laurent, M.; Trypaluk, C.; Unruh, D.; Yekta, M.; Bonnin, G. NOAA Atlas 14, Volume 8 Precipitation-Frequency Atlas of the United States, Midwestern States, Version 2; US National Oceanic and Atmospheric Administration: Silver Spring, MD, USA, 2013.

66. Wilson, C.; Kampf, S.K.; Wagenbrenner, J.W.; MacDonald, L.H. Rainfall thresholds for post-fire runoff and sediment delivery from plot to watershed scales. For. Ecol. Manag. 2018, 430, 346-356. [CrossRef]

67. Winchell, M.F.; Jackson, S.H.; Wadley, A.M.; Srinivasan, R. Extension and validation of a geographic information system-based method for calculating the Revised Universal Soil Loss Equation length-slope factor for erosion risk assessments in large watersheds. J. Soil Water Conserv. 2008, 63, 105-111. [CrossRef]

68. NRCS Soil Survey Staff. Web Soil Survey; USDA Natural Resources Conservation Service: Washington, DC, USA, 2016. Available online: https://websoilsurvey.nrcs.usda.gov/ (accessed on 23 August 2016).

69. Larsen, I.J.; MacDonald, L.H. Predicting post-fire sediment yields at the hillslope scale: Testing RUSLE and disturbed WEPP. Water Resour. Res. 2007, 43, W11412. [CrossRef]

70. Henkle, J.E.; Wohl, E.; Beckman, N. Locations of channel heads in the semiarid Colorado Front Range, USA. Geomorphology 2011, 129, 309-319. [CrossRef]

71. Ryan, S.E.; Dwire, K.A.; Dixon, M.K. Impacts of wildfire on runoff and sediment loads at Little Granite Creek, western Wyoming. Geomorphology 2011, 129, 113-130. [CrossRef]

72. Schmeer, S.R. Post-Fire Erosion Response and Recovery, High Park Fire, Colorado. Master's Thesis, Colorado State University, Fort Collins, CO, USA, 2014. 
73. Sham, C.H.; Tuccillo, M.E.; Rooke, J. Effects of Wildfire on Drinking Water Utilities and Best Practices for Wildfire Risk Reduction and Mitigation; Report 4482; Water Research Foundation: Denver, CO, USA, 2013.

74. Writer, J.H.; Hohner, A.; Oropeza, J.; Schmidt, A.; Cawley, K.M.; Rosario-Ortiz, F.L. Water treatment implications after the High Park Wildfire, Colorado. J. Am. Water Works Assn. 2014, 106, 189-199. [CrossRef]

75. Sherriff, R.L.; Platt, R.V.; Veblen, T.T.; Schoennagel, T.L.; Gartner, M.H. Historical, observed, and modeled wildfire severity in montane forests of the Colorado Front Range. PLoS ONE 2014, 9, e106971. [CrossRef]

76. Davis, L.S. The Economics of Wildfire Protection with Emphasis on Fuel Break Systems; California Division of Forestry: Sacramento, CA, USA, 1965.

77. Wilson, A.A.G. Width of firebreak that is necessary to stop grass fires: Some field experiments. Can. J. For. Res. 1988, 18, 682-687. [CrossRef]

78. Mees, R.; Strauss, D.; Chase, R. Modeling wildland fire containment with uncertain flame length and fireline width. Int. J. Wildland Fire 1993, 3, 179-185. [CrossRef]

79. Agee, J.K.; Bahro, B.; Finney, M.A.; Omi, P.N.; Sapsis, D.B.; Skinner, C.N.; van Wagtendonk, J.W.; Weatherspoon, C.P. The use of shaded fuelbreaks in landscape fire management. For. Ecol. Manag. 2000, 127, 55-66. [CrossRef]

80. O'Connor, C.D.; Calkin, D.E. Engaging the fire before it starts: A case study from the 2017 Pinal Fire (Arizona). Wildfire Mag. 2019, 28, 14-18.

81. Ingalsbee, T. Ecological fire use for ecological fire management: Managing large wildfires by design. In Proceedings of the Large Wildland Fires Conference, Missoula, MT, USA, 19-23 May 2014; Keane, R.E., Matt, J., Parsons, R., Riley, K., Eds.; Proceedings RMRS-P-73. USDA Forest Service Rocky Mountain Research Station: Fort Collins, CO, USA, 2015; pp. 120-127.

82. Blake, D.; Nyman, P.; Nice, H.; D’Souza, F.M.L.; Kavazos, C.R.J.; Horwitz, P. Assessment of post-wildfire erosion risk and effects on water quality in south-western Australia. Fire 2020, 29, 240-257. [CrossRef]

83. Moody, J.A.; Shakesby, R.A.; Robichaud, P.R.; Cannon, S.H.; Martin, D.A. Current research issues related to post-wildfire runoff and erosion processes. Earth Sci. Rev. 2013, 122, 10-37. [CrossRef]

84. Robichaud, P.R.; Lewis, S.A.; Wagenbrenner, J.W.; Ashmun, L.E.; Brown, R.E. Post-fire mulching for runoff and erosion mitigation Part I: Effectiveness at reducing hillslope erosion rates. Catena 2013, 105, 75-92. [CrossRef]

85. Robichaud, P.R.; Wagenbrenner, J.W.; Brown, R.E.; Wohlgemuth, P.M.; Beyers, J.L. Evaluating the effectiveness of contour-felled log erosion barriers as a post-fire runoff and erosion mitigation treatment in the western United States. Int. J. Wildland Fire 2008, 17, 255-273. [CrossRef]

86. Robichaud, P.R.; Wagenbrenner, J.W.; Lewis, S.A.; Ashmun, L.E.; Brown, R.E.; Wohlgemuth, P.M. Post-fire mulching for runoff and erosion mitigation Part II: Effectiveness in reducing runoff and sediment yields from small catchments. Catena 2013, 105, 93-111. [CrossRef]

87. Ferro, V.; Porto, P. Sediment Delivery Distributed (SEDD) Model. J. Hydrol. Eng. 2000, 5, 411-422. [CrossRef]

88. Fernandez, C.; Wu, J.Q.; McCool, D.K.; Stöckle, C.O. Estimating water erosion and sediment yield with GIS, RUSLE, and SEDD. J. Soil Water Conserv. 2003, 58, 128-136.

89. Rhoades, C.C.; Entwistle, D.; Butler, D. The influence of wildfire extent and severity on streamwater chemistry, sediment and temperature following the Hayman Fire, Colorado. Int. J. Wildland Fire 2011, 20, 430-442. [CrossRef]

90. Kampf, S.K.; Brogan, D.J.; Schmeer, S.; MacDonald, L.H.; Nelson, P.A. How do geomorphic effects of rainfall vary with storm type and spatial scale in a post-fire landscape? Geomorphology 2016, 273, 39-51. [CrossRef]

91. Diodato, N.; Bellocchi, G. Reconstruction of seasonal net erosion in a Mediterranean landscape (Alento River Basin, Southern Italy) over the past five decades. Water 2019, 11, 2306. [CrossRef]

92. Hohner, A.K.; Cawley, K.; Oropeza, J.; Summers, R.S.; Rosario-Ortiz, F.L. Drinking water treatment response following a Colorado wildfire. Water Res. 2016, 105, 187-198. [CrossRef]

93. Salis, M.; Del Giudice, L.; Robichaud, P.R.; Ager, A.A.; Canu, A.; Duce, P.; Pellizzaro, G.; Ventura, A.; Alcasena-Urdiroz, F.; Spano, D.; et al. Coupling wildfire spread and erosion models to quantify post-fire erosion before and after fuel treatments. Int. J. Wildland Fire 2019, 28, 687-703. [CrossRef]

94. Chambers, M.E.; Fornwalt, P.J.; Malone, S.L.; Battaglia, M.A. Patterns of conifer regeneration following high severity wildfire in ponderosa pine-dominated forests of the Colorado Front Range. For. Ecol. Manag. 2016, 378, 57-67. [CrossRef] 
95. Fornwalt, P.J.; Huckaby, L.S.; Alton, S.K.; Kaufmann, M.R.; Brown, P.M.; Cheng, A.S. Did the 2002 Hayman Fire, Colorado, USA, burn with uncharacteristic severity? Fire Ecol. 2016, 12, 117-132. [CrossRef]

96. Collins, B.M.; Stevens, J.T.; Miller, J.D.; Stephens, S.L.; Brown, P.M.; North, M.P. Alternative characterization of forest fire regimes: Incorporating spatial patterns. Landsc. Ecol. 2017, 32, 1543-1552. [CrossRef]

97. Calkin, D.E.; Cohen, J.D.; Finney, M.A.; Thompson, M.P. How risk management can prevent future wildfire disasters in the wildland-urban interface. Proc. Natl. Acad. Sci. USA 2014, 111, 746-751. [CrossRef]

C 2020 by the authors. Licensee MDPI, Basel, Switzerland. This article is an open access article distributed under the terms and conditions of the Creative Commons Attribution (CC BY) license (http://creativecommons.org/licenses/by/4.0/). 